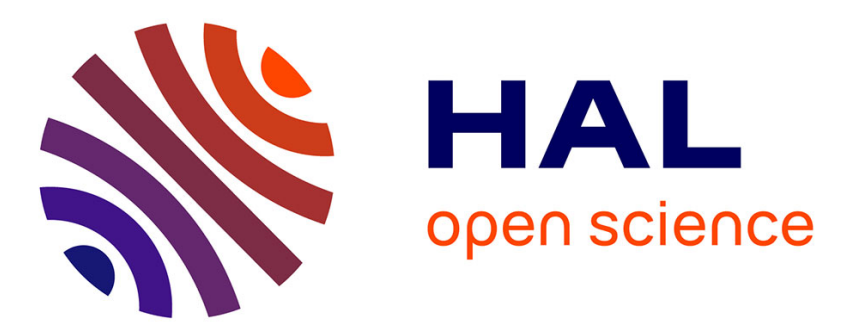

\title{
The role of identity and authority from anarchy to order: Insights from modeling the trajectory of dueling in Europe
}

Mehrdad Vahabi, Behrooz Hassani-Mahmooei

\section{- To cite this version:}

Mehrdad Vahabi, Behrooz Hassani-Mahmooei. The role of identity and authority from anarchy to order: Insights from modeling the trajectory of dueling in Europe. Economic Modelling, 2016, 55, pp.57-72. 10.1016/j.econmod.2016.02.005 . hal-02196941

\section{HAL Id: hal-02196941 \\ https://hal.science/hal-02196941}

Submitted on 30 Jul 2019

HAL is a multi-disciplinary open access archive for the deposit and dissemination of scientific research documents, whether they are published or not. The documents may come from teaching and research institutions in France or abroad, or from public or private research centers.
L'archive ouverte pluridisciplinaire HAL, est destinée au dépôt et à la diffusion de documents scientifiques de niveau recherche, publiés ou non, émanant des établissements d'enseignement et de recherche français ou étrangers, des laboratoires publics ou privés. 


\title{
The role of identity and authority from anarchy to order: Insights from modelling the trajectory of dueling in Europe
}

\author{
Mehrdad Vahabi and Behrooz Hassani-Mahmooei
}

\begin{abstract}
Economic literature usually assumes order in terms of a Weberian state with monopoly over the means of violence. In this paper, we study historical situations in which such an order is absent and violent conflict namely duel of honor is an institution. Anarchy or the absence of state rules in managing violence does not imply the absence of private rules and arrangements (such as codes of dueling). Our focus is on the possible ways that a Weberian order can emerge from anarchy. We endeavor to capture this transition by introducing a computational model in which a simulated agent represents a social individual who considers both economic and political factors and interacts with other individuals as well as institutions to make a decision. We then use the trajectory of dueling in England, France, and Germany to validate our approach. The paper demonstrates how a complex, aggregative historical process over three centuries may be consistently explained on the basis of rational choices among heterogeneous agents conditioned by their group identity and State authority.
\end{abstract}

Keywords: Agent-based Computational Economics, Conflict theory, Duel of honor, Identity Economics, Orderly anarchy.

JEL: C63, D02, D74, N43, P16

Research Highlights:

- We study the dynamics of transition from anarchy to order.

- Transition is better understood if a representative agent is replaced by a social agent.

- A social agent has an identity that evolves and interacts with other agents and authority.

- Using a computational model, we simulate the trajectory of dueling in Europe.

- Our methodology can be used to understand failed states and their transition to order. 


\section{Introduction}

Change, transition and evolution are undeniable aspects of social systems and so any socialscientific theory that does not address them will be considered incomplete (Haferkamp and Smelser, 1992). The Blackwell Dictionary of Sociology defines social change as 'any alteration in the cultural, structural, population, or ecological characteristics of a social system such as a society'. More specifically, according to Rogers (1971), social change is a process through which two main dimensions of a society, namely its structure and its functions, will be altered; as a result of which, all other aspects of life in a society, including the state and dynamics of its economy will be affected due to these sudden or gradual transitions.

Social order, can be defined as either "the totality of structured human interrelationships in a society or a part of it ${ }^{1 \text { " }}$ or as an opposite to 'chaos'. In both senses, it is among the major components of change and transition in the society, since it represents the state of both social structure and its functioning including the dynamics of values, relations, and institutions.

In economic literature, the meaning of 'order' and 'chaos' has been scrutinized further. In their pioneering model on 'Anarchy', Bush and Mayer (1974) introduced a distinction between 'anarchy' and chaos. While the latter pertains to the absence of any rule, 'anarchy' can be conceived of a society without a state but not without rules. In this sense, a Weberian state with monopoly over the means of violence provides a benchmark for 'order'. Public choice economics introduced a vast research project (see for detailed surveys, Stringham, 2005 and 2007) focusing on how an 'orderly anarchy' might persist. In this perspective, one of the main research topics has been "how individuals interact without government?" and whether "central authority is not needed to create or enforce a legal system governing intergroup interactions" (Leeson, 2009; Powell \& Stringham, 2009). For example, while Somalia has been classified as a "failed state" by the Failed States Index ${ }^{2}$, Leeson and Williamson (2009) characterize it as a benchmark of anarchy and claim that anarchic Somalia outperforms many Sub-Saharan African (SSA) countries that have governments. "If state predation under predatory political governance is severe enough, anarchy can produce higher welfare." (2009, p. 88). The merits of such a research program in understanding 'failed states' notwithstanding, it does not focus on the transition from anarchy (failed states) to order (Weberian state). Similarly, a major question is how political stability can emerge from the present

\footnotetext{
${ }^{1} \mathrm{http}: / /$ www.merriam-webster.com/dictionary/social\%20order

${ }^{2}$ The classification is established by Foreign Policy and the Fund for Peace, see Foreign Policy/Fund for Peace, Failed States Index, accessible at www.fundforpeace.org and http://foreignpolicy.com
} 
anarchy in countries like Afghanistan, Iraq, Libya, and Syria. While lots of attention is now paid to transition from order to anarchy during events such as Arab Spring, the processes through which a new order might establish from a chaotic situation in the Middle East region is sometimes overlooked.

We believe that this can be due to two main reasons: 1) the fact that fewer theoretical frameworks are available to explain the transition from anarchy to order, and 2) the nature of the transition from anarchy to order makes it hard to validate and verify the theoretical models that already exist.

We argue that, to model, comprehend and explain transition from anarchy to order, we need to understand the two main players of social change, namely, individual and society. The main challenge that the current literature is facing, especially in economics, is that an individual is often regarded as a 'representative' agent without any social identity and interaction with other individuals and society. On the other hand, society is understood as aggregative bodies particularly through structures, laws and regulations that do not directly interact with individuals.

This study contributes to better understand social transitions in four major areas.

First, following Akerlof and Kranton (2000), we attach identity to our agent and define it as a "social individual" instead of a "representative agent". By gaining identity, this individual will then be able to represent a specific group of members of the society. This allows us to change the size and identity of each group so that it can represent an evolving social group through time. .

Then, we introduce "authority". In economics, institutions as formal and informal rules (North, 1990) are usually regarded as constraints on the agent's choice but not as part of his/her utility function. But if agents are considered as social agents (for example aristocrats versus commoners), their institutional attachment is no more a constraint in defining their utility function but is rather part of their utility function as suggested by Akerlof \& Kranton (2010). In line with the literature on law and economics, in our model, institution not only embraces the role of formal law, but also captures the evolution of this role in response to the decisions made by the social individual. In this sense, we adopt an institutionalist approach in which individual preferences are not given exogenously.

Third, we allow the agents and authority to interact at three levels. Firstly, there will be an intergroup interaction where the agent will affect and will be affected by its peers. Then, members 
of different groups will have impact on each other's decisions, and finally our social individual and the authority interact.

Finally, we apply an advanced computational modelling technique on a historical case of transition from anarchy to order, namely duel of honor. This type of violent conflict was an institution that lasted over three centuries in Europe. Its emergence and evolution is a complex social phenomenon involving the role of individual's social identity and military skill as well as formal and informal problems with the state enforcement of laws. The efficiency of the computational technique has already been acknowledged by evolutionary economics (Dosi et al. 2009; Dosi et al. 2010) and public choice economics (Wallick, 2012). In this paper, we will show why this technique may be of interest to the institutionalist approach. In fact, in contrast to other modelling techniques, computational economics do not need 'simplification'. Deep and specific knowledge about of duel of honor as an aristocratic institution throughout history can be distilled in the assumptions of each of stages of the model. In this way, the model integrates all the relevant stylized facts of a complex social phenomenon. While institutional knowledge enrichens the model, the model provides all theoretically possible historical trajectories including the counterfactual ones. The complex social reality is then understood not as a fatal destiny but only as one possibility among many others that occurred due to 'path dependency'. From a methodological point of view, this paper tries to reconcile an institutionalist approach with theoretical or analytic narrative through advanced computational techniques.

The next section provides a critical survey on duel of honor in economic literature. Section III introduces our theoretical model of dueling in four steps: each step involves adding a new feature, in an attempt to replicate the trajectory of dueling observed in Europe. Section IV validates the model based on historical evidence from England, France, and Germany over three centuries, and Section V presents our conclusions.

\section{The state of art on duel of honor in economic literature}

While social historians and legal scholars have investigated various features of dueling on the basis of culture, honor, gender, or court substitution in Europe, North America, and Latin America, economists and economic historians have ignored of dueling as an 'exotic institution' until recently.

Game theorists have been interested in strategies about when to shoot (Kurisu, 1983, 1991), but overlooked dueling as a social institution. To our knowledge, Volckart (2004) was the first to 
model a similar phenomenon, specifically feuding in late medieval Germany. However, duel of honor is not the same as feuding, vendettas, brawls, jousts, or tournaments.

In addition to Volckart's work, two recent papers (Allen and Reed, 2006; Kingston and Wright, 2010) have presented efficiency explanations for dueling. ${ }^{3}$ However, these papers address only the motivation of a rational individual duelist and neglect the broader question of dueling as a transitional social institution, an issue that has been discussed extensively by social historians and legal scholars. Allen and Reed (2006) suggested that the duel served as a screening device separating marginal aristocrats who had not invested in unobservable social capital within a social context in which patronage and trust were important mechanisms for monitoring political exchanges. They argued that "when patronage was ultimately replaced by a professional bureaucracy based on merit, dueling ceased to be practiced" (Allen and Reed, 2006, p. 88). If their argument is correct, then why did the duel particularly persist in France and Germany at the end of the nineteenth century despite the existence of a modern professional state bureaucracy based on merit? The real issue is not whether dueling was 'efficient' or 'inefficient,' but why dueling norms persisted despite the changing political and social factors that undermined their efficiency. According to Max Weber, dueling has a peculiar transitional character that results from contradictory orders ${ }^{4}$. By 'contradictory orders', he referred to the fact that although the duel was expressly forbidden by the Criminal Code in Germany, "the readiness to participate in a duel is still a legal obligation imposed by the state upon its army officers" (Weber 1968, p. 318). In this sense, the question about dueling was not whether it was legally and socially valid or not, but how these two contradictory norms and institutions could coexist together and could these contradictory orders evolve through time (Weber, Ibid., p. 32). Kingston and Wright (2010) neglected this transitional character, describing dueling as a signal about an unobservable intangible asset: personal creditworthiness. Their model assumes that an 'honorable' man is one who can be trusted to repay loans. It also assumes that "there is no formal enforcement mechanism in place" (Kingston and Wright, 2010, p. 1098) - but dueling does exist as a transitional phenomenon under conditions of contradictory orders, such as incomplete formal state enforcement coexisting either with informal aristocratic community enforcement or military enforcement (a state within the state) as in Germany at the end of the nineteenth century.

\footnotetext{
${ }^{3}$ Gagné (2007) developed a non-formalized model of dueling in which agents pretend to comply non-rationally while feigning not to notice that most others do the same.

4 For simplicity, hereafter we will use the shorter term 'contradictory orders' instead of Weber's original term of 'contradictory systems of order.'
} 
The paucity of models about dueling is related to the fact that dueling is not studied within the broader context of the transition from anarchy to order. Economists and economic historians have recently begun to investigate the problem of political transitions and the relationships between social order and violence (Acemoglu and Robinson, 2001, 2008; North et al., 2009; North et al., 2013; Vahabi, 2016). This study contributes to the growing body of literature about the ruleproducing or institutional dimension of conflictual activity, by examining dueling as a social institution under contradictory orders or within a transition period.

The duel of honor is one of the best indicators of social and political transition from the older feudalism of fragmented political power to a stronger, centralizing monarchy. It lasted much longer in France than in England, and longer in Germany than in France. This process corresponds to Hobbes's transition from anarchy to Leviathan. Borrowing from public choice literature, while aristocratic civil wars can be regarded as chaos, and the monopoly of violence by the state as Leviathan (order), the duel of honor is anarchy (or an 'orderly anarchy' ${ }^{5}$ ), because it entails extra legal or illegal strictly codified and regulated private conflict.

A duel of honor is "a fight between two or several individuals (but always equal numbers on either side), equally armed, for the purpose of proving either the truth of a disputed question or the valor, courage and honor of each combatant. The encounter must be decided or accepted jointly by both parties and must respect certain formal rules, be they tacit, oral or written, which will give it the weight of a legal proceeding, at least in the eyes of the two adversaries" (Billacois, 1990, p. 5). Dueling is thus a strictly codified private fight, ${ }^{6}$ negotiated and mediated by 'seconds.' The duel of honor should be distinguished from both the judicial duel (trial by combat) and dueling for chivalry (Baldick, 1965, pp. 11-32). The judicial duel was presided over by a public authority, i.e., the sovereign prince, whereas the duel of honor was usually illegal ${ }^{7}$ and privately organized. The eminent French sociologist Gabriel Tarde $(1892,30)$ distinguished the judicial duel from German's divinatory duel, defining the judicial duel as a transitional form of dueling between German's divinatory duel and the duel of honor. Leeson (2011) analyzed the judicial duel or 'trial by battle' within a Coasean paradigm in allocating contested property rights.

\footnotetext{
${ }^{5}$ For a detailed discussion of 'orderly anarchy,' see Powell and Stringham (2009).

${ }^{6}$ Two treaties about the code of dueling were published in the 1590s (Stone, 1965, 245). Many codes of dueling were published since, including the code duello adopted at the Clonmel Summer Assizes, 1777; this contained 26 rules that were reprinted in Truman $(1883,48-53)$.

${ }^{7}$ Malta in Italy was one of the few places in which dueling was permitted by law in the sixteenth century. It was legally confined to the army in Sardinia; see Baldick (1965, pp. 142, 144).
} 
The judicial duel can be traced back to A.D. 501, but the duel of honor was first described in Italy by 'doctors of duels' or 'professors of honor' between the 1360s (Giovanni da Legnano) until around 1560 (Muzio, Possevino). Their theories became known as chivalric science (scienza cavalleresca). Duels were popular in Italy, but the practice particularly flourished in France as an aristocratic social institution during the sixteenth and the seventeenth centuries and continued until the First World War. Dueling was introduced in England as a French fashion and persisted there until the first half of the nineteenth century. Germany also imported this French fashion, where it experienced a kind of golden age at the end of the nineteenth century (McAleer, 1994, pp. 22-23). Dueling later spread to English colonies, including the United States and Canada.

The duel of honor is a particular type of conflictual procedure that is unrelated to appropriating a subject of predation such as a resource, wealth, or any other kind of endowment, as reported in Garfinkel and Skaperdas (2007). Instead, it is a privately arranged way to manage violence through the self-organizing and self-regulating collective actions of influential social groups such as aristocrats. Thus, the duel of honor is an institution that appears during the transitional period between anarchy and order, and the sudden or gradual withering of this institution marks the transition to the monopoly of violence by the state.

Analysis of this institution can help clarify at least two major issues: 1) the role of identity investment by heterogeneous individual agents in shortening or lengthening the transition from anarchy to order; and 2) the extent to which the emergence of order is related to the place of the army within the state, and the ability of the state to enforce its rules and preclude private arrangements of violence management. These issues are of historical importance, but are also relevant today in emerging and developing countries with failed states experiencing political transitions in the Middle East, Africa and Latin America.

A comprehensive analysis of the duel of honor requires focusing on three levels: individuals (duelers), their identity ${ }^{8}$ (lower and higher nobility, officers, and later the middle class), and state organization (particularly the army and the judicial or royal power). Little empirical quantitative evidence is available about the emergence of dueling in Europe in the sixteenth century and its evolution until the end of the nineteenth century. Although we have explored all the available

\footnotetext{
${ }^{8}$ Please see Step 2 of Section 2 for a more detailed definition of identity.
} 
sources about the duel of honor in Europe, the dearth of data requires using other methods to illustrate this complex interaction of different variables. In our opinion, a simulation applying ABM is a promising avenue.

Heckbert et al. $(2010,40)$ defined agent-based modeling as "the computational study of systems of interacting autonomous entities, each with dynamic behavior and heterogeneous characteristics.” In the field of economics, this is known as Agent-based Computational Economics (ACE): "the computational study of economies modeled as evolving systems of autonomous interacting agents" (Tesfatsion et al., 2006, 264). From this perspective, economy is seen as a complex adaptive system, in which macro-level phenomena are the emergent outcomes of micro-level decisions and interactions. In this kind of model (Holland, 1992), a computer simulates an 'agent' - a set of features and functions that can represent different entities, ranging from an individual to a community, an organization, or even a physical object (LeBaron and Tesfatsion, 2008). ABM has been used to explore the complexities involved in various social and economic models such as economic growth and business cycles (Dosi et al., 2009 and Dosi et al., 2010), Finance (Liu et al., 2014 and Riccetti et al., 2015), civil violence and conflict (Epstien, 2002, Hassani-Mahmooei and Parris, 2013), and consumer behavior (Kirman and Vriend, 2001).

Wallick $(2012,224)$ noted that ABM provides two main features: "support for arbitrarily heterogeneous actors" and "support for adaptive behavior." It enables scholars to determine how heterogeneous interactions at the individual level are caused by shifts from one state of equilibrium to another, and thereby to trace the dynamics back to their original causes at the micro level. Because our work involves heterogeneity, network effects, and emergence, ABM is a particularly relevant way to model gradual changes as well as punctuated equilibriums, and to clarify the effects of individual decisions as well as social multipliers.

\section{Theoretical Model}

This section introduces a theoretical model that can identify which factors affected the duration and lethality of dueling. Based on these factors, we developed this model in four steps to show the dynamics within a simulated environment. At each step, we verified the success of the model in replicating the available historical evidence about dueling.

No reliable statistics are available about the numbers of duels and the number of people killed during duels, but French and English historians have collected many 'impressionistic statistics' (Billacois, 1990) from the emergence of dueling in the second half of the sixteenth century until the 
second half of the seventeenth century (Billacois, 1990; Cockburn, 1720; Kiernan, 1988; McAleer, 1994; Stone, 1965). Because insufficient evidence is available to simulate agents' behaviors in detail, we used a minimalistic approach, including only the modules, behaviors, and actions that can be supported by historical evidence. Some previous research has focused on the pre-engagement decision of dueling (Kingston and Wright, 2010), here, we focus on how the dueling engagement decision is made in the presence of a conflictual situation between two agents. Borrowing from Boulding (1962), our model assumes three main levels in decision-making: 1) the individual; 2) the group; and 3) the organization.

\section{Step 1: The Individual}

The model begins with $n$ agents. Each agent, $i$, is part of a network consisting of a group of agents, $\mathrm{Ni}$, representing the social community with whom each agent will interact during the simulation. The network provides us with two things: first, the opportunity to implement an informationsharing framework similar to an agent's real-world experience; second, it ensures the agent's decision is affected not only by its own experiences, but also by monitoring the experiences of others. The number of links for each agent is a random value uniformly distributed between 1 and a variable called network-size. Figure 1 presents two sample network structures.

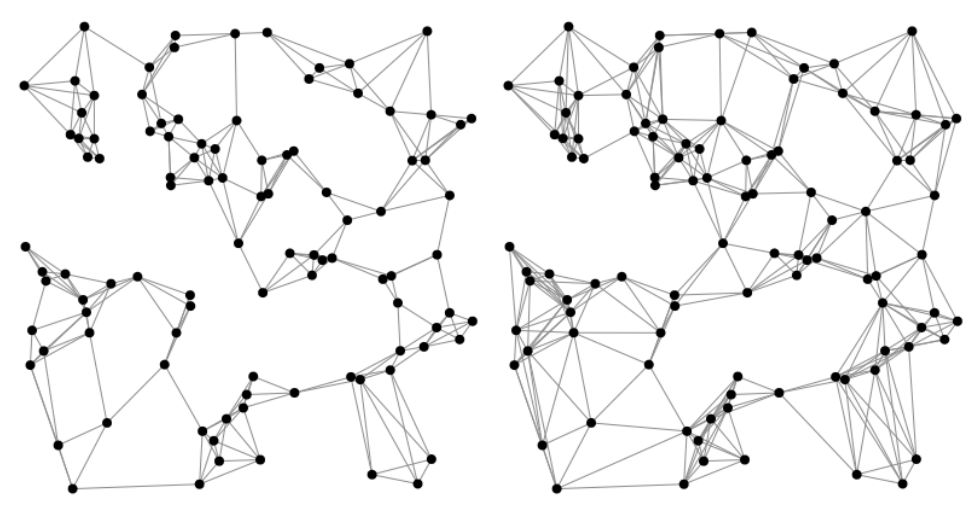

Figure 1: Two sample network structures with 200 agents and low (left) and high (right) linkage density.

When encountered with a conflict situation, each agent has different options, or strategies; the agent selects one strategy from a pool of strategies, represented by a three-bit vector such as $\left[\mathrm{X}_{1} \mathrm{X}_{2} \mathrm{X}_{3}\right]$. Each bit can be 0 or 1 , leading to a pool of eight different strategies. The first bit, $X_{1}$, is 1 if the agent is interested in taking the conflict to the court; $\mathrm{X}_{2}$ is 1 if non-lethal dueling is preferred; and $\mathrm{X}_{3}$ is 1 if the agent is interested in lethal dueling. For instance, if agent $i$ 's strategy is [ 101$]$, this 
means that when a conflict arises between agent $i$ and another agent, he ${ }^{9}$ prefers that conflict to be taken to the court or settled in a lethal duel.

Lethal and non-lethal duels are separated in this model because historical evidence indicates that pistol duels could only be terminated by death or by the exchange of agreed-upon number of shots; in contrast, sword duels (by sabre, rapier, or épée) could be terminated after an injury produced a flow of blood. ${ }^{10}$ In Europe, the sabre was more likely to be used by army officers, while the rapier was monopolized by the aristocracy (Muchembled, 2012, p. 174) and required a certain level of skill. The épée was more accessible to commoners (Jeanneney, 2004, p. 35), which is why the épée (probably the least favored of the three sanctioned weapons before 1848) rose to prominence as the appropriate weapon for settling disputes of honor in the Third Republic (Guillet, 2008, p. 202; Reddy, 1997, p. 257). Table 1 summarizes the use of the three major dueling weapons during the 1880s.

Table 1: Dueling instruments in 1880s France

\begin{tabular}{|l|l|l|}
\hline Epée & Sabre & Pistol* \\
\hline $89 \%$ & $1 \%$ & $10 \%$ \\
\hline
\end{tabular}

Source: Data are based on Nye (1993, p. 186). Not all pistol duels were lethal, because they were often fought at a greater and safer distance during this period. Approximately 500 duels occurred per year.

Table 2 lists all possible options in the strategy pool. Later, we will discuss why we selected this framework to present strategies. Along with strategies, each agent has a variable called beststrategy, which keeps a record of the strategy that has yielded the highest level of utility within the simulation. The agent does not have an infinite memory; it can only remember the last best strategy it selected and replace it with a new strategy, if it leads to a higher level of utility.

\footnotetext{
${ }^{9}$ Duelers were generally male, because dueling by women was banned in all European countries. However, female duels occurred occasionally (Frevert, 1991, p. 287); Tarde (1892, p. 42) referred to such duels as an exotic phenomenon.

${ }^{10}$ The choice of pistol versus épée was not only a technical matter, but also a philosophical issue on which two different schools were opposed. One recommended pistols, because the outcome depended on mere 'luck' - the other recommended épées, considering this to involve more 'bravery' (Jeanneney, 2004, pp. 34-39). Guy de Maupassant, who considered the duel "a stupid necessity imposed by human foolishness," argued that the pistol duel is the consistent type of dueling (1883, pp. v-viii). German gentlemen engaged lethal pistol barrier duels that limited the number of shooting rounds and involved a longer distance between duelers. German student dueling involved rapiers or, in more serious cases, sabres and padding that resulted in facial scars (Frevert, 1991, p. 277).
} 
Table 2: List of strategies in the strategy pool and their symbols

\begin{tabular}{|l|l|l|}
\hline Strategy & Symbol & Interpretation \\
\hline$\left[\begin{array}{lll}0 & 0 & 0\end{array}\right]$ & I & Agent takes no action and ignores the conflict in any case \\
\hline$\left[\begin{array}{lll}1 & 0 & 0\end{array}\right]$ & C & Agent prefers to take the conflict to court \\
\hline$\left[\begin{array}{lll}0 & 1 & 0\end{array}\right]$ & N & Agent prefers to do non-lethal dueling \\
\hline$\left[\begin{array}{lll}0 & 0 & 1\end{array}\right]$ & L & Agent prefers to do lethal dueling \\
\hline$\left[\begin{array}{lll}1 & 1 & 0\end{array}\right]$ & CN & Agent chooses between going to court or non-lethal dueling, but excludes lethal dueling. \\
\hline$\left[\begin{array}{lll}0 & 1 & 1\end{array}\right]$ & LN & Agent chooses between lethal or non-lethal dueling, but excludes going to court. \\
\hline$\left[\begin{array}{lll}1 & 0 & 1\end{array}\right]$ & CL & $\begin{array}{l}\text { Agent chooses between going to court and doing lethal dueling, but excludes non-lethal } \\
\text { dueling. }\end{array}$ \\
\hline$\left[\begin{array}{lll}1 & 1 & 1\end{array}\right]$ & CNL & Agent is indifferent between the strategies. \\
\hline
\end{tabular}

I: Ignore, C: Court, N: Non-lethal, L: Lethal.

Each agent also has a variable called skill, indicating his expertise in dueling. An agent's skill is not fixed over the simulation time: when an agent engages in a duel and wins, his skill increases with a diminishing rate as presented in Equation 1, where the skill of agent $i$ at time $t\left(s k i l l_{i t}\right)$ is a function of his initial skill $\left(\right.$ skillio $\left._{i}\right)$ and the number of his wins so far $\left(W_{i t}\right)$.

$$
\operatorname{skill}_{i t}=\operatorname{skill}_{i 0}+\sqrt{W_{i t}}
$$

Although different weapons were used for dueling during the period under study in the specific regions, for simplicity the model considers skill to represent the agent's average skill in all the possible instruments, whether the duel is lethal or non-lethal.

The unit of time is called a 'tick,' which designates a timeframe in which the probability of each of the simulation functions to be executed is more than zero. To provide a sense of the real world, we consider each tick to represent the duration of one week. The model starts with tick $=1$ and runs for 100 years, so the total simulation is 5,200 ticks $^{11}$ long.

Over the course of the simulation, agents reproduce at a fixed rate, $r$. The initial population, $n$, is 200 agents, which grows by $100 \%$ over the simulation time, based on the population growth in Europe between 1800 (203 million) and 1900 (408 million; see United Nations, 2008). This pertains to the three main case studies we will introduce later.

\footnotetext{
${ }^{11}$ For simplicity we consider each year to have exactly 52 weeks.
} 
When the model initializes, at every tick a probability of conflict emerges, $P_{\text {conflict }}$, in which the agent is involved. $P_{\text {conflict }}$ is between zero and 1 and is similar for all agents. For every tick, each agent can engage into conflict with any, but only one, other agent in the environment. When two agents are involved in a conflict, and considering that each of them has one of the eight possible discussed strategies, 64 outcomes are possible, as presented in Table 3.

Table 3: Strategy combinations and the final outcome

\begin{tabular}{|c|c|c|c|c|c|c|c|c|c|}
\hline & \multicolumn{9}{|c|}{ Agent 2} \\
\hline & & I & C & $\mathbf{N}$ & $\mathbf{L}$ & $\mathrm{CN}$ & $\mathbf{L N}$ & CL & CNL \\
\hline \multirow{8}{*}{ Agent 1} & I & W & W & W & W & W & $\mathrm{W}$ & W & W \\
\hline & C & $\mathrm{W}$ & $\mathrm{C}$ & $\mathrm{W}$ & $\mathrm{W}$ & $\mathrm{C}$ & $\mathrm{W}$ & $\mathrm{C}$ & $\mathrm{C}$ \\
\hline & $\mathbf{N}$ & W & W & $\mathrm{N}$ & $\mathrm{U}$ & $\mathrm{N}$ & $\mathrm{N}$ & $\mathrm{U}$ & $\mathrm{N}$ \\
\hline & $\mathbf{L}$ & W & W & $\mathrm{U}$ & $\mathrm{L}$ & $\mathrm{U}$ & $\mathrm{L}$ & $\mathrm{L}$ & $\mathrm{L}$ \\
\hline & $\mathbf{C N}$ & W & $\mathrm{C}$ & $\mathrm{N}$ & $\mathrm{U}$ & $\mathrm{CN}$ & $\mathrm{N}$ & $\mathrm{CU}$ & $\mathrm{CN}$ \\
\hline & $\mathbf{L N}$ & W & W & $\mathrm{N}$ & $\mathrm{L}$ & $\mathrm{N}$ & $\mathrm{U}$ & $\mathrm{L}$ & $\mathrm{U}$ \\
\hline & CL & W & $\mathrm{C}$ & $\mathrm{U}$ & $\mathrm{L}$ & $\mathrm{CU}$ & $\mathrm{L}$ & CL & CL \\
\hline & CNL & W & $\mathrm{C}$ & $\mathrm{N}$ & $\mathrm{L}$ & $\mathrm{CN}$ & $\mathrm{U}$ & CL & $\mathrm{CU}$ \\
\hline
\end{tabular}

W: Withdraw, I: Ignore, C: Court, L: Lethal, N: Non-lethal, U: Undetermined

As shown in Table 3, the model has four outcome categories. First, when at least one agent ignores the conflict (I), no further action will be taken by the agents and they will both withdraw ${ }^{12}$. Second, if no common strategy is shared between the agents, e.g., one wants to go to court and the other prefers lethal dueling, again both parties ignore the conflict. Third, when both agents have similar strategies (e.g., C and C), or there is only one common letter in their strategies (e.g., CNL and C), then that common action will be adopted by both agents. Finally, if there is more than one common strategy (e.g., CL vs. CNL or CNL vs. CNL), the final outcome will be chosen randomly with an equal probability given to each possible outcome.

At the end of this process, the agents agree on how they want the conflict to be settled based on four possible outcomes: 1) ignore, 2) court, 3) non-lethal duel, and 4) lethal duel. If the agents decide to withdraw, no further actions will be undertaken. If they decide to go to court, the model assumes that one will win and the other will lose, and each have a 50\% chance of winning. If two agents decide to duel (lethal or non-lethal), the outcome is determined using a Tullock (1980) contest

\footnotetext{
${ }^{12}$ If the outcome of Court-Ignore pair is Court instead of Withdraw, then the model dynamics will not significantly change and all the results presented in the paper will hold.
} 
success function $(\mathrm{CSF})^{13}$ in which the probability of agent $i$ winning over agent $j, P_{i}\left(W_{j}\right)$ is determined through a function, as shown in Equation 2. In our model, $m$ is considered to be 1 .

$$
P_{i t}\left(W_{j}\right)=\frac{\text { skill }_{i t}{ }^{m}}{\text { skill }_{i t}{ }^{m}+\text { skill }_{j t}{ }^{m}}
$$

Table 4 presents the utility of winning or losing a duel, after the winner is identified. In a lethal duel, the winner wins everything and the loser dies, represented by $-\infty$. However, the outcomes are less certain in non-lethal dueling. Here, random is used as a function that returns a random real number between 0 and $\gamma$, so that in the non-lethal case the loser loses a random amount between 0 and $-\gamma$ (due to a nonfatal injury). As $-\infty$ may not be accommodated in later mathematical analysis, when the model is implemented, it is replaced with a large negative but finite number equal to the average of network-size. This implies that if an agent dies in a duel, on average, he would only require one level of his network to change his decision in the next round. At the end of this stage, each agent gains a utility based on his own and his opponent's decisions and actions. Because agents know the utility they derive from their actions, they undertake two more steps.

Table 4: Utility for each of the potential conflictual actions of an agent

\begin{tabular}{|l|l|l|}
\hline Action & Utility for Winner & Utility for Loser \\
\hline Court & 1 & 0 \\
\hline Lethal Duel & 1 & $-\infty$ \\
\hline Non-Lethal Duel & 1 & - Random $(\gamma)$ \\
\hline
\end{tabular}

First, each agent shares his findings with the other agents in his network. In this process, each agent $i$, who has a strategy such as strategy, will measure the average utility of his network neighbors who chose the same strategy during their last conflict situation. ${ }^{14}$ Through this process, agents calibrate their perception regarding the likely utility that can be gained from adopting that strategy. Second, agents apply a learning module to improve their decision based on their own gained utility. This learning process can be captured using a genetic framework. As discussed above, an agent's strategy is presented as $\left[\mathrm{X}_{1} \mathrm{X}_{2} \mathrm{X}_{3}\right]$. The implemented framework has one mutation and one

\footnotetext{
${ }^{13}$ Hirshleifer (1989) distinguished between two types of contest success functions: ratio versus difference models of relative success. Skaperdas (1996) axiomatized the CSF employed in most contests as well as two most frequently used functional forms of this function. Clark and Riis (1998) extended this axiomatization. Kooreman and Schoonbeek (1997) provided an alternative set of axioms, resulting in a modified version of the Tullock CSF, regarding the asymmetry between players. For an analysis of three classes of CSF and their relevance in different types of contests see Konrad (2009, Chapter 2).

${ }^{14}$ Due to the lack of historical evidence, instead of implementing a learning algorithm, we have only enabled agents to share information with agents who have chosen a similar strategy pertaining to the fact that agents communicate with each other and can mutually influence each other's choice.
} 
crossover operator. Over the simulation time, the agents randomly change parts of their strategy by mutating a randomly-selected bit in their strategy from 0 to 1 or vice versa, in an attempt to experience the other available strategies in the pool and shift to a strategy with higher utility, if such a strategy exists. At the same time, they keep a record of the strategy with the highest utility ${ }^{15}$ (beststrategy) and do a crossover between their current strategy and the best strategy, to ensure that they are optimizing their actions constantly by learning from experience. ${ }^{16}$

The model is implemented using NetLogo 5.0.2 (Wilensky, 1999), which has been widely used in the social sciences for agent-based modeling. ${ }^{17}$ Considering the above-mentioned rules and conditions discussed for Step 1, Figure 1 presents the duration of a dueling era under 10 individual single model runs, each representing a sample randomly taken from 100 simulations. The trends illustrate the sum of both lethal and non-lethal dueling.

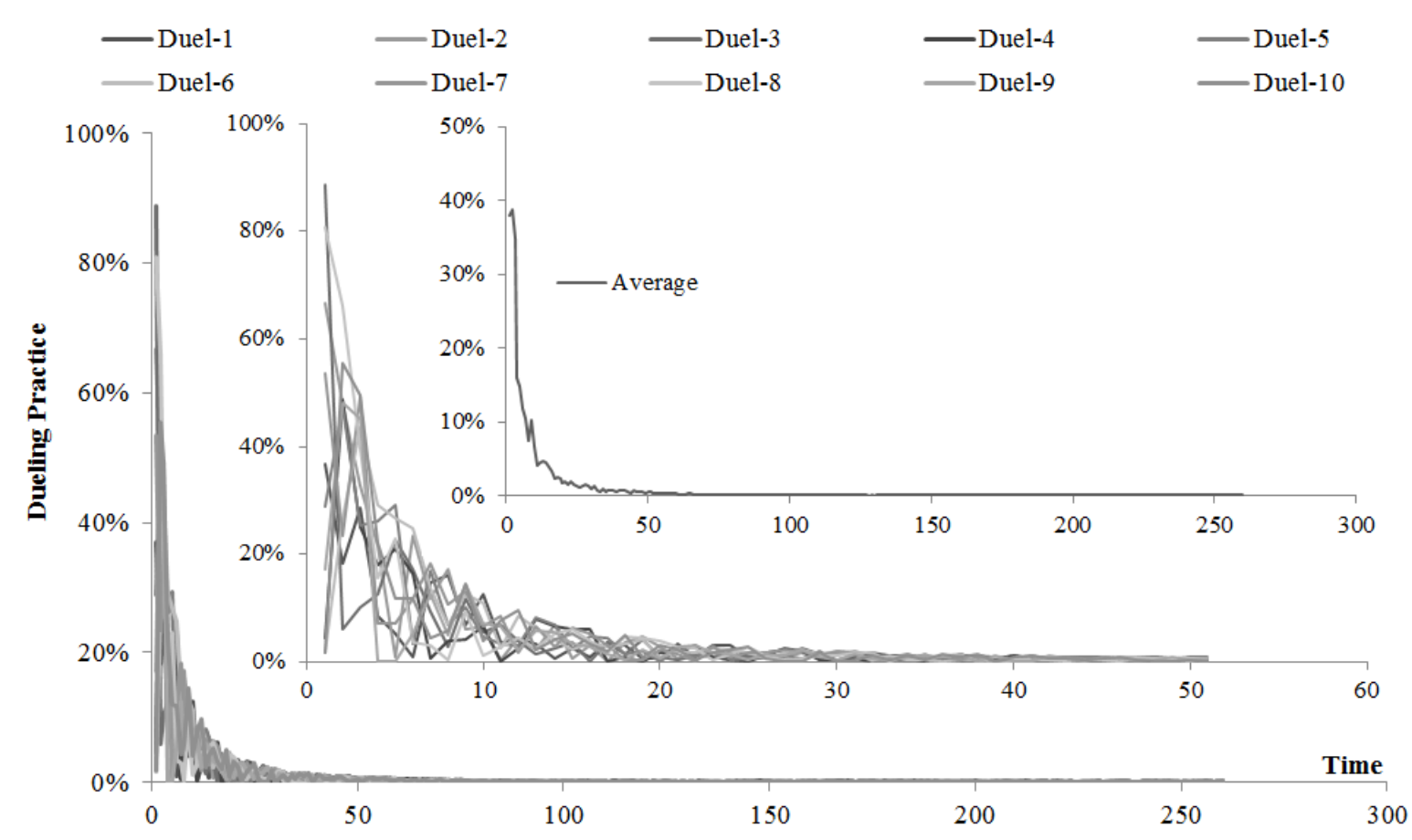

Figure 2: Dueling when only the individual is taken into account. This figure presents the results of 1,000 simulations, with each line randomly representing 1 of 100 runs. The largest graph shows the changes in dueling over the shortened time period of 260 steps (5\% of the total duration). The middle graph zooms in on the first 50 steps (1\% of the total simulation). The smallest graph presents the average trends in the simulations.

\footnotetext{
${ }^{15}$ Agents do not record all the utility values derived from each strategy; they only record the strategy with the highest utility. This means that they do not need an infinite memory or the ability to remember the maximum utility for each possible strategy. They simply need to keep the best strategy, represented by a [X1 X2 X3] format.

${ }^{16}$ Further details and examples are provided in the supplementary material.

${ }^{17}$ The pseudo code of the simulation program is freely available to interested scholars.
} 
As shown in Figure 2, if agents only take into account their gained utilities, even if they consider the experiences of their network members and learn through the model, dueling would not survive for long. According to the model results, the Step 1 model will settle on an equilibrium in which less than $1 \%$ of agents will duel, and more than $80 \%$ will choose to go to court. The model will not produce a zero-dueling environment, because the mutation operator will keep activating the dueling bits, so the probability of an encounter involving two duelers is very low but not zero ${ }^{18}$.

The average trend can be well estimated using a power model with a formula such as $y=\rho e^{-x}$ representing the sudden fall in the dueling practice. This fall is mainly due to the combined individual learning process and information-sharing through the network, which leads agents not to partake in a low-utility activity for a long time.

\section{Step 2: Adding Identity}

Step 1 demonstrated that it is not possible to use a simple utility model, even when enriched with learning and networking, to describe the appearance and disappearance of dueling in our simulated environment. So, how can the economist's rational choice theoretical framework handle the preference of individuals for dueling and its long persistence in various countries when considered as an emerging public choice issue?

In the heyday of dueling, choosing to duel was a sort of answer to the existential question of 'to be or not to be' - a choice that was mainly only available to the aristocracy (but not commoners) who behaved according to the code of honor.

Obviously, a decision to duel is not like the usual economic choice of apple versus orange; the choice depends on the agent's identity, i.e., the social categories to which an individual belongs (see e.g., Akerlof and Kranton, 2000; 2010). These categories are associated with certain socially determined 'self-images' that include an ensemble of 'prescriptions' or behavioral rules to which an individual complies in accordance with his/her attachment to these categories. Accordingly, the norms of how to behave depend on an individual's position within his/her social context. 'Identity economics' extends the utility function by adding an agent's identity to his/her individual

\footnotetext{
${ }^{18}$ Except for extreme parameters such as very high negative court payoffs (as in a corrupted judicial system) or unrealistic conditions such as utility of lethal duel being zero for the loser in our sensitivity analysis, we did not find parameter values under which duelling (would stand?) stands on a statistically significant non-zero level in long-term.
} 
preferences or tastes. Does any historical evidence support the role of identity in decisions about dueling?

During the sixteenth and seventeenth centuries, Europe underwent a period of intense social, political, and religious tension and conflict. The aristocracy, the old ruling class, was in crisis and disintegrating into its various strata. It needed something to unite its ranks and restore cohesion. In other words, the collective action of the aristocracy needed a mechanism to shun free-riding and strategic behavior among its individual members. Dueling, and its associated code of honor, provided a social glue to unite lower and upper aristocracy during this transitional period. According to Demeter, the duel "strengthened their sense of belonging to a single privileged class" (1965, p. 119). Borrowing some terminology from identity economics (Akerlof and Kranton, 2010), the duel of honor provided identity, purity, and distinction to the aristocracy as the legitimate heir of the nobility of the sword from feudal times. It gave the entire class a military character and encouraged its patronage of new mass armies, while the new parliament and courts enabled the nascent bourgeoisie and lawyers to have an increasingly strong influence.

Upper and lower aristocracy both benefited from dueling. By claiming the right to duel, the high nobility was symbolically showing that it had not surrendered its independent spirit to the monarchy. Dueling only appeared when the nobility was the "principal nerve of our state" (Billacois, 1990, p. 98), and "when the monarchial model blurs, when the model of a deliberating assembly, a parliament in the most etymological sense of the word, takes over" (ibid, p. 30).

Lower aristocracy benefited from dueling for another reason. The practice was most common among minor country gentry or squires, "who hunt in the day, get drunk in the evening, and fight the next morning" (Young, 1925, p. 205). The enjoyment factor cannot be discounted, as the lives of country gentry tended to be monotonous, ${ }^{19}$ but the major advantage of dueling was its leveling effect: "The duel was the sign and seal of a mystic equality between higher and lower, a fraternal bond uniting the whole multifarious class. It was, in short, a leveler, even though in practice a peer would oftenest be embroiled with one of his own kind, a squire with another of the squires (...) A duke ought to accept a challenge from a simple gentleman, Selden argued, because by treating him improperly the duke brought himself to the same level" (Kiernan, 1988, p. 52).

\footnotetext{
${ }^{19}$ Checkov (1921, p. 30) referred to this 'fun factor': "When there is no war, they are bored".
} 
Considering the available evidence about the role of identity in how micro-economic decisions will lead to a macro-level public choice about dueling, and following Boulding (1962) framework, a new level can now be added to the model, called group $(G)$. Each agent now belongs to a group of: aristocrats $(A)$; the middle class $(M)$; or commoners $(C)$.

To accommodate the identity module in the model, four variables are also added. Three variables control the proportion of agents who belong to each of three groups, $P_{A}, P_{M}$, and $P_{C}$, referring to aristocrats, the middle class, and commoners, respectively, where $P_{A}+P_{M}+P_{C}=1$. Aristocrats have an additional variable, aristo-level, representing their level of aristocracy, which is set to zero for commoners and the middle class and is distributed normally with a mean of 1 and a flexible standard deviation, called $s d$, between 0 and $0.25,{ }^{20}$ for aristocrats. Higher values of standard deviation indicate wider social differences between the aristocrats themselves and thus less unity among them. Middle-class agents are separated from the commoners by a Boolean variable called midclass?, which is True for middle-class agents and False for commoners.

Some of variables defined in Step 1 can also be updated at this point. First, based on historical evidence (Nye, 1993; Jeanneney, 2004), we expect the average skill to be higher for aristocrats than for the middle class and commoners. So, if $A_{i}$ represents agent $i$ and $G$ represents the identity groups, ${ }^{21}$ we have:

$$
\left\langle\operatorname{skill}_{i} \mid A_{i} \in\left(G_{M} \cup G_{C}\right)\right\rangle<\left\langle\operatorname{skill}_{i} \mid A_{i} \in G_{A}\right\rangle
$$

Second, for each agent, the network is formed so that the majority of its members are from a similar group and fewer members are agents who belong to other groups. For instance, if agent $i$ is an aristocrat, then majority of its network members will be aristocrats, and so from $G_{A}$ a smaller portion will belong to $G_{M}$ and $G_{C}$. Equation 1 shows the probability of agent $j$ being a member of agent $i$ 's neighbors if agent $i$ belongs to $G_{X}$, where $G_{\bar{X}}$ presents the agents belonging to a different group. In such a setting, if $p\left(A_{j} \in N_{i} \mid A_{j} \in G_{X}\right)$ is equal to $\rho$, then $p\left(A_{j} \in N_{i} \mid A_{j} \in G_{\bar{X}}\right)$ will be $1-\rho$.

$$
p\left(A_{j} \in N_{i} \mid A_{j} \in G_{X}\right)>p\left(A_{j} \in N_{i} \mid A_{j} \in G_{\bar{X}}\right)
$$

\footnotetext{
20 The value is selected in a way to ensure that the aristocracy-level is always between 0 and 2 , and for majority of the individuals it is between 0.5 and 1.5 .

${ }^{21}$ While the model allows agents to have different levels of dueling skills linked to their identity (and later authority), it does not allow agents to make decisions about dueling based on their own or their opponent's skill. This assumption may be unrealistic, but it is consistent with the fact that changes in the length of the dueling era will only be associated with IO and IS, rather than changes in skill.
} 
The decision process for the agents is similar to what was introduced in Tables 2 and 3. But how does adding identity affect the outcome table?

According to Akerlof and Kranton (2000, p. 728), if an agent belonging to an identity group takes an action that is not consistent with his group's activity, he loses his identity which then leads to "a reduction in utility of $I_{s}$, where the subscript $s$ stands for self" and other members of that group will also experience "a loss in utility $I_{o}$, where the subscript $o$ denotes other." Our model follows the same pattern. Table 5 presents the updated values for outcome; two major changes to Step 1 are introduced. First, for every action taken by agents, $I S_{i}$ and $I O_{i}$ now provide the identity component of the utility. Second, $s d$ ensures that if aristocrats duel, then the advantages of their action will appear in their utility function. Coefficients $\alpha_{1}, \alpha_{2}$, and $\alpha_{3}$ are used to calibrate the effects of each factor on utility.

Table 5: Utility for each of the potential conflictual actions of an agent

\begin{tabular}{|l|l|l|}
\hline Action & Utility for Winner & Utility for Loser \\
\hline Court & $1+\alpha_{1} . I S_{i}+\alpha_{2} . I O_{i}$ & $0+\alpha_{1} . I S_{i}+\alpha_{2} . I O_{i}$ \\
\hline Lethal Duel & $1+\alpha_{1} . I S_{i}+\alpha_{2} . I O_{i}+\alpha_{3} s d$ & $-\infty+\alpha_{1} . I S_{i}+\alpha_{2} \cdot I O_{i}+\alpha_{3} s d$ \\
\hline Non-Lethal Duel & $1+\alpha_{1} . I S_{i}+\alpha_{2} . I O_{i}+\alpha_{3} s d$ & - Random $(1)+\alpha_{1} . I S_{i}+\alpha_{2} . I O_{i}+\alpha_{3} s d$ \\
\hline
\end{tabular}

In the model, $I S_{i}$ will be a randomly distributed number between 0 and 1 , if the agent chooses an action consistent with its group (duel for aristocrats and court for non-aristocrats) and between -1 and 0 , if the agent's activity is not consistent with his identity (duel for non-aristocrats and court for aristocrats). As shown in Equation 5, when agent $i$ takes action $a_{i}$ at time $t, I O_{i} \mid a_{i t}$ is measured by dividing the number of agents in his network who have adopted the same action by the total number of his related agents. $I O_{i}$, which is between 0 and 1 , indirectly provides us with a value for how the decision of one agent who undertakes a specific action may affect the utility gained by other agents according to the action they have taken.

$$
I O_{i} \mid a_{i t}=\frac{\#\left\{A_{j}: A_{j} \in N_{j} \vee a_{i t}=a_{j t}\right\}}{\#\left\{A_{j}: A_{i} \in N_{i}\right\}}
$$

Figure 3 presents the results of the model under the Step 2 configuration. Compared with the results of Step 1, the dueling persists much longer, because the identity component provides an incentive for the aristocrats to duel more. Also, while minor changes in $s d$ may not affect the duration of the dueling period, greater differences (and hence larger $s d$ values) motivate more agents, specifically aristocrats, to consider dueling an activity with high utility, at least for a short time. 


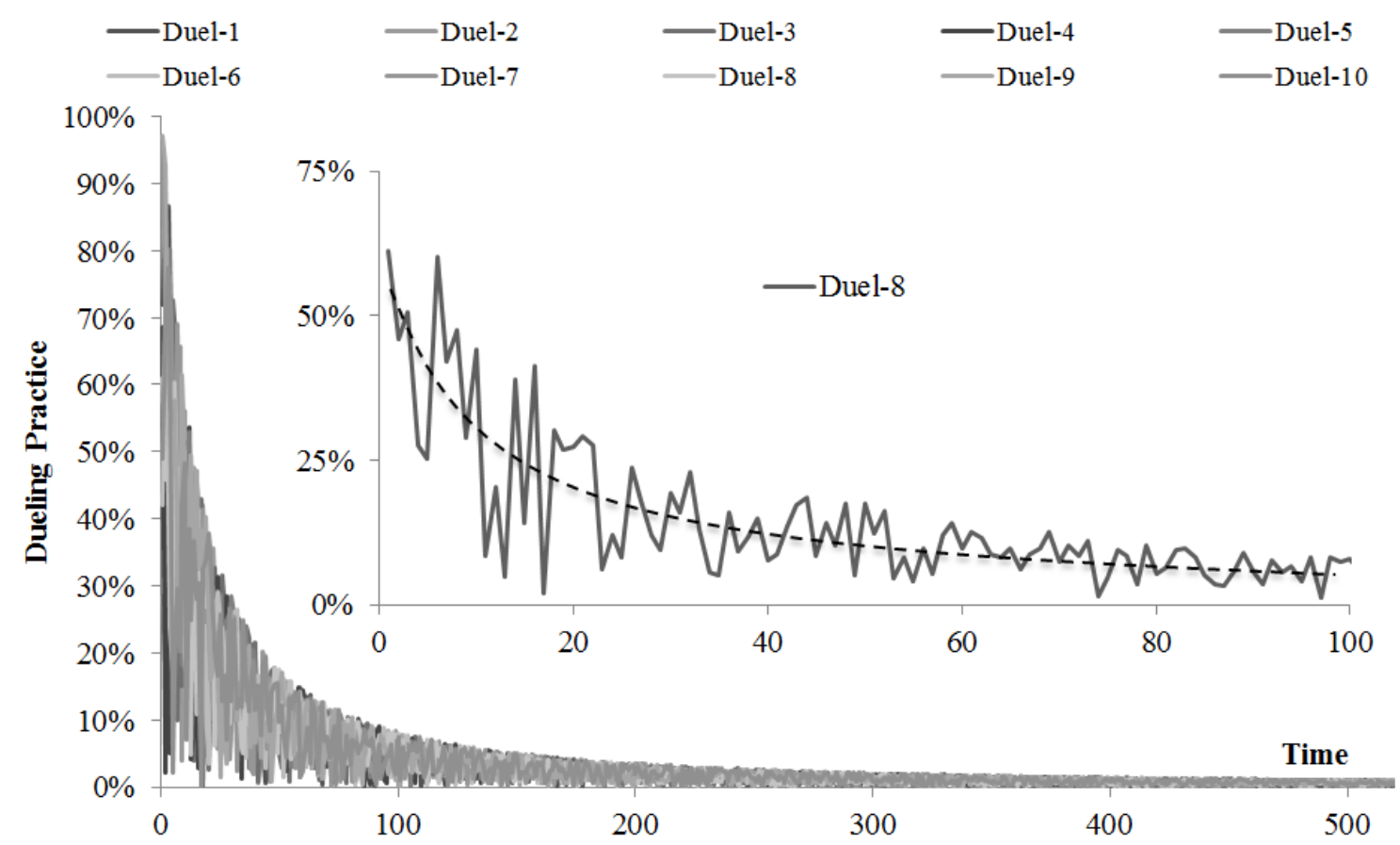

Figure 3: Dueling trend in an environment including identity. The outside figure shows the changes for 10 randomly selected sample simulations out of 1,000 runs and the smaller plot presents the trends for one randomly selected simulation.

Note that $I S, I O$, and $s d$ affectivity is highly related to the size of the aristocracy group, so if aristocrats are not a large part of the whole simulated community, then the role of identity will be less significant.

\section{Step 3: Adding Authority}

The previous step demonstrated that adding identity can help explain the dueling phenomenon, but we have not yet formulated an integral model to explore the dueling macro patterns. What other evidence is available to improve the model?

Historians have identified a link between weakened royal authority, civil war, and increased dueling. A strong and stable absolutist monarchy is more able to control this kind of activity: the practice never took root in Spain, where the undisputed authority of the Catholic Church and the monarchy were united in banishing the duel. The Spanish aristocracy preferred bullfighting, as did commoners. $^{22}$

\footnotetext{
${ }^{22}$ Billacois (1990, pp. 38-39) explained how cultural factors affected the banishment of dueling in Spain. He argued that because honor was not a conquest but a family treasure, the duel could not re-establish a contested honor.
} 
Table 6 presents the trough periods and Table 7 presents the peak periods of dueling in France where dueling originated, based on these impressionistic statistics.

Table 6: Trough periods of dueling in France

\begin{tabular}{|ll|}
\hline Trough period & Political situation \\
\hline $\mathbf{1 6 1 8}-\mathbf{1 6 2 1}$ & Resurgence of politico-religious conflict in Europe \\
\hline $\mathbf{1 6 3 7}-\mathbf{1 6 4 9}$ & France's open participation in the general European conflict \\
\hline
\end{tabular}

Table 7: Peak periods of dueling in France

\begin{tabular}{|c|c|c|}
\hline $\begin{array}{l}\text { Peak } \\
\text { period }\end{array}$ & Political situation & $\begin{array}{l}\text { Estimated number of } \\
\text { deaths }\end{array}$ \\
\hline $1562-1598$ & $\begin{array}{l}\text { Valois dynasty, crippled royal authority } \\
\text { Chain of civil wars under religious pretext }\end{array}$ & $8,000 *$ \\
\hline $1604-1607$ & $\begin{array}{l}\text { Peace at home and abroad (Peace of Vervain) } \\
\text { Disputed authority of Henry IV }\end{array}$ & $6,000 * *$ \\
\hline 1611-1614 & $\begin{array}{l}\text { Minority of Louis XIII } \\
\text { Meeting of the Estates General }\end{array}$ & \multirow{4}{*}{$25,000 * * *$} \\
\hline $1621-1626$ & $\begin{array}{l}\text { Richelieu as a strong minister } \\
\text { Military operations against the Protestant fraction }\end{array}$ & \\
\hline $1631-1633$ & $\begin{array}{l}\text { Period of 'covert war,' France managing to delay its entry } \\
\text { in the Thirty Years' War }\end{array}$ & \\
\hline $1649-1653$ & $\begin{array}{l}\text { Following the Treaty of Westphalia and the partial re- } \\
\text { establishment of peace abroad, civil wars collectively } \\
\text { known as the Fronde (Catapult) of the princes }\end{array}$ & \\
\hline & Total & 39,000 \\
\hline
\end{tabular}

*Kiernan (1988, p. 75); Chesnais (1981, p. 104) estimated 7,000- 8,000 deaths during the 1590s. **Stone (1965, p. 246) reported 6,000 pardons by the king from 1600-1610; Tarde (1892, p. 43) estimated 7,000-8,000 deaths during the period 1589-1608. ***McAleer (1988, p. 18) estimated an average of 500 deaths annually from 1610-1660. Major Truman (1884, p. 22) estimated that the 'dreadful mania' took 20,000 lives, "more gentle blood than thirty years of civil war", and Chesnais (1981, pp. 103-104) reported 30,000 deaths for the period 1610-1640. Considering the latter estimation, the total amounts to 43,000 deaths.

An overview of the peak and trough periods reveals two findings. First, increased dueling is likely to be related to weakened royal authority, either because a monarch was too young (e.g., Louis XIII and Louis XIV), or because a monarch's right to rule was disputed (e.g., Henri III and Henri IV until 1598). Second, civil war stimulated dueling, whereas foreign war usually reduced the number of duels. The Thirty Years' War and the civil wars collectively known as the Fronde (catapult) 
encouraged dueling, especially because they undermined the authority of the sovereign. Foreign wars, if supported by public opinion, were a source of internal unity and effectively discouraged dueling among gentlemen. Similar results appear for Britain; the duel of honor appeared in England around 1590 (Cockburn, 1720), and as in France, increased in prevalence until 1620. The rates of increase were similar in the two countries until 1600, when the rate in France increased faster than in England. The disparity was especially obvious from 1610-1620 (Billacois, 1990), and dueling rates declined sharply in England after 1620 (Stone, 1965). Dueling experienced a resurgence in England from $1644-1655,{ }^{23}$ before and during the English Civil War.

Historical evidence also reveals that a double standard (or contradictory orders) encourages dueling, as has been widely observed in Germany, where social militarization occurred causing the formation of a state within a state. From its inception in the last third of the sixteenth century, the duel was regarded as part of 'caste honor' (standesehre) among persons worthy of carrying swords (satisfaktionsfähig): aristocrats and officers, state officials, and students. Friedrich Wilhelm I of Prussia, the so-called 'Soldier-King' (1713-1740) adumbrated the fundamental link between dueling and militarism, and McAleer noted, "Duels were undertaken out of a feeling of coresponsibility for the collective reputation of Germany's social elite, out of a sort of tribal egotism, and not from a selfish amour proper" $(1994,35)$.

A double standard between 'military honor' and 'civilian honor' was instituted after the Prussian Law Code of 1794: a duel could only take place among officers and noblemen; armed clashes among other civilians, including the bourgeoisie, were handled by criminal law. Civilians were thus denied treatment under the dueling statutes. The conflict of principle between military and civil concepts of honor became strikingly public when Eritz Anneke, a Prussian second lieutenant, was dismissed from the army in 1846 based on his refusal to duel with a fellow officer. After its investigation, the military court of honor ruled out the possibility of cowardice and attributed Anneke's decision to his “communist and democratic notions” (McAleer, 1994, pp. 26-35).

Based on this evidence, and again following Boulding (1962), we can now add a new level to the model: 'organization.' This is represented by two major authorities: state and military. The state runs the courts and the military is in charge of the army. An individual who is subject to state laws is a 'civilian,' and an individual in the army who is subject to both state and military laws is an

\footnotetext{
${ }^{23}$ Cromwell banned the duel in 1654. In the United States, the War of Independence stimulated the practice of dueling, but "the Civil War killed the duel" (Wells, 2001, p. 1838).
} 
'officer.' Adding authority to the model helps address the concerns identified by Buchanan and Tollison (1984, p. 13) and later discussed by Wallick (2012, p. 232) about the monolithic modelling of political entities such as government, as separate from agents. With the addition of authority, our model allows two different organizations (state and army) to affect how individuals make decisions.

At this point, six different identity-authority categories can be defined, as listed in Table 8 .

Table 8: Identity categories of the model in Step 3

\begin{tabular}{|c|c|c|c|c|}
\hline & Authority & Group & Category Title & Symbol \\
\hline 1 & \multirow{3}{*}{ State } & Aristocrat & Aristocrat Civilian & $\mathrm{C}_{\mathrm{AC}}$ \\
\hline 2 & & Middle-Class & Middle-Class Civilian & $\mathrm{C}_{\mathrm{MC}}$ \\
\hline 3 & & Commoner & Commoner Civilian & $\mathrm{C}_{\mathrm{CC}}$ \\
\hline 4 & \multirow{3}{*}{ Military } & Aristocrat & Aristocrat Officer & $\mathrm{C}_{\mathrm{AO}}$ \\
\hline 5 & & Middle-Class & Middle-Class Officer & $\mathrm{C}_{\mathrm{MO}}$ \\
\hline 6 & & Commoner & Commoner Officer & $\mathrm{C}_{\mathrm{CO}}$ \\
\hline
\end{tabular}

Organization-level features are accommodated in the model using three variables. First, officers-tocivilians shows how agents are distributed between the officers and civilians. The state is represented using a variable, $P_{\text {state, }}$, ranging between 0 and 1 , which indicates the probability of a wrongdoing to be detected and punished by the state. The army's power is presented with a variable, $P_{\text {military }}$, also between 0 and 1 , indicating the military's supremacy in the simulated society and its ability to punish officers who do not respect military rules.

The definition of skill initially introduced in Step 2 can now be updated. Based on historical evidence, we expect the average skill to be higher for aristocrats than non-aristocrats, and higher for officers than civilians, so:

$\left\langle\operatorname{skill}_{i} \mid A_{i} \in\left(C_{M C} \cup C_{C C}\right)\right\rangle<\left\langle\right.$ skill $\left._{i} \mid A_{i} \in C_{A C}\right\rangle\left\langle\left\langle\right.\right.$ skill $\left._{i} \mid A_{i} \in\left(C_{M O} \cup C_{C O}\right)\right\rangle<\left\langle\right.$ skill $\left._{i} \mid A_{i} \in C_{A O}\right\rangle$

Also, using the same symbols as those used in Step 2, the network structure and connection probabilities can be updated as follows.

$$
p\left(A_{j} \in N_{i} \mid A_{j} \in C_{X Y}\right)>p\left(A_{j} \in N_{i} \mid A_{j} \in\left(C_{\bar{X} Y} \cup C_{X \bar{Y}}\right)\right)>p\left(A_{j} \in N_{i} \mid A_{j} \in C_{\bar{X} \bar{Y}}\right)
$$

According to Equation 7, the probability of agent $j$ being a member of agent $i$ 's social network if agent $i$ belongs to $\mathrm{C}_{\mathrm{XY}}$ can be expressed as Equation 1, where $C_{\bar{X} Y}$ represents agents from a similar group as $A_{i}$ but following a different authority and $C_{X \bar{Y}}$ represents agents of similar authority as $A_{i}$ 
but belonging to a different group. This time, if agent $i$ is an aristocrat civilian, then majority of his social network members will be aristocrat civilians and so from $\mathrm{C}_{\mathrm{AC}}$, fewer will belong to $\mathrm{C}_{\mathrm{MC}}, \mathrm{C}_{\mathrm{CC}}$, and $\mathrm{C}_{\mathrm{AO}}$ and the fewest will come from $\mathrm{C}_{\mathrm{MO}}$ and $\mathrm{C}_{\mathrm{CO}}$. In such a setting, if $p\left(A_{j} \in N_{i} \mid A_{j} \in C_{X Y}\right)$ is equal to $\rho$, then $p\left(A_{j} \in N_{i} \mid A_{j} \in\left(C_{\bar{X} Y} \cup C_{X \bar{Y}}\right)\right)$ will be $n \rho$, and $p\left(A_{j} \in N_{i} \mid A_{j} \in C_{\bar{X} \bar{Y}}\right)$ will be $m \rho$, where $\rho+n \rho+m \rho=1$ and $n>m$ and $n+m>(1-n-m)$. The values of $\rho, n$, and $m$ are set as initial conditions and vary across the experiments.

To include the response of authority to an action undertaken by agents, a new component is added to the outcome table: $A R$, representing the net responses received from the state and the military, as shown in Table 9. Here, $A R_{i}=\beta_{1}$.Random $\left(P_{\text {state }}\right)+\beta_{2 .}$ Random $\left(P_{\text {military }}\right)$, where the values of $\beta_{1}$ and $\beta_{1}$ are dependent on the agent's category and action, as listed in Table 10.

Table 9: Utility for each of the potential conflictual actions of an agent

\begin{tabular}{|l|l|}
\hline Action & Utility for Winner \\
\hline Court & $1+\alpha_{1} I S_{i}+\alpha_{2} . I O_{i}+\alpha_{3} . A R_{i}$ \\
\hline Lethal Duel & $1+\alpha_{1} . I S_{i}+\alpha_{2} . I O_{i}+\alpha_{3} s d$ (Aristo) $+\alpha_{4 . A R_{i}}$ \\
\hline Non-Lethal Duel & $1+\alpha_{1} I S_{i}+\alpha_{2} . I O_{i}+\alpha_{3} s d$ (Aristo) $+\alpha_{4} . A R_{i}$ \\
\hline Action & Utility for Loser \\
\hline Court & $0+\alpha_{1} . I S_{i}+\alpha_{2} . I O_{i}+\alpha_{3} . A R_{i}$ \\
\hline Lethal Duel & $-\infty+\alpha_{1} . I S_{i}+\alpha_{2} . I O_{i}+\alpha_{3} s d($ Aristo $)+\alpha_{4} . A R_{i}$ \\
\hline Non-Lethal Duel & - Random $(1)+\alpha_{1} . I S_{i}+\alpha_{2} . I O_{i}+\alpha_{3} s d($ Aristo $)+\alpha_{4} . A R_{i}$ \\
\hline
\end{tabular}

Table 10: Utility coefficients

\begin{tabular}{|l|l|l|}
\hline & Civilian & Officer \\
\hline Duel (lethal or non-lethal) & $\beta_{1}=-\tau$ & $\beta_{1}=-\tau$ \\
& $\beta_{2}=0$ & $\beta_{2}=\tau$ \\
\hline Court & $\beta_{1}=0$ & $\beta_{1}=0$ \\
& $\beta_{2}=0$ & $\beta_{2}=-\tau$ \\
\hline$\tau>0$ & \multicolumn{2}{|l}{} \\
\hline
\end{tabular}

Table 9 provides a set of simple rules: if a civilian or an officer duels, he will be punished by the government, whereas if an officer goes to court, he might be punished by the military. Considering the modules added during Step 3, we expect the model to have more complex processes because, for instance, for every agent, at any point in time, four different factors will affect the decision: 1) his personal learning, 2) the experience of his network members, 3) his identity, and finally 4) the 
reaction from authorities. These factors will lead to a final decision made over time and across the agents.

The results of this step can be summarized using two figures. Figure 4 presents overall trends in dueling changes across three sample simulations. The solid line represents a case in which state and military authorities almost neutralize each other, so the model response pattern is very similar to that observed in Step 2. As the military gains further authority power, the demise of dueling will be delayed (dashed and dotted lines), although the fixed dueling rate is not sustainable and dueling finally disappears over time. The main reason behind the delay and change in the pattern from the solid to the other two lines is that as military gains more power dueling will be encouraged, both directly via pressure on officers and also indirectly due to increasing returns in investment identity. However, this line of conflictual action will be undermined as more agents (especially aristocrats and officers) encounter the disadvantages of dueling and share this with others. Once this countertendency is triggered, it can even reach a point at which officers join the rest of agents in not adopting the strategy of dueling.

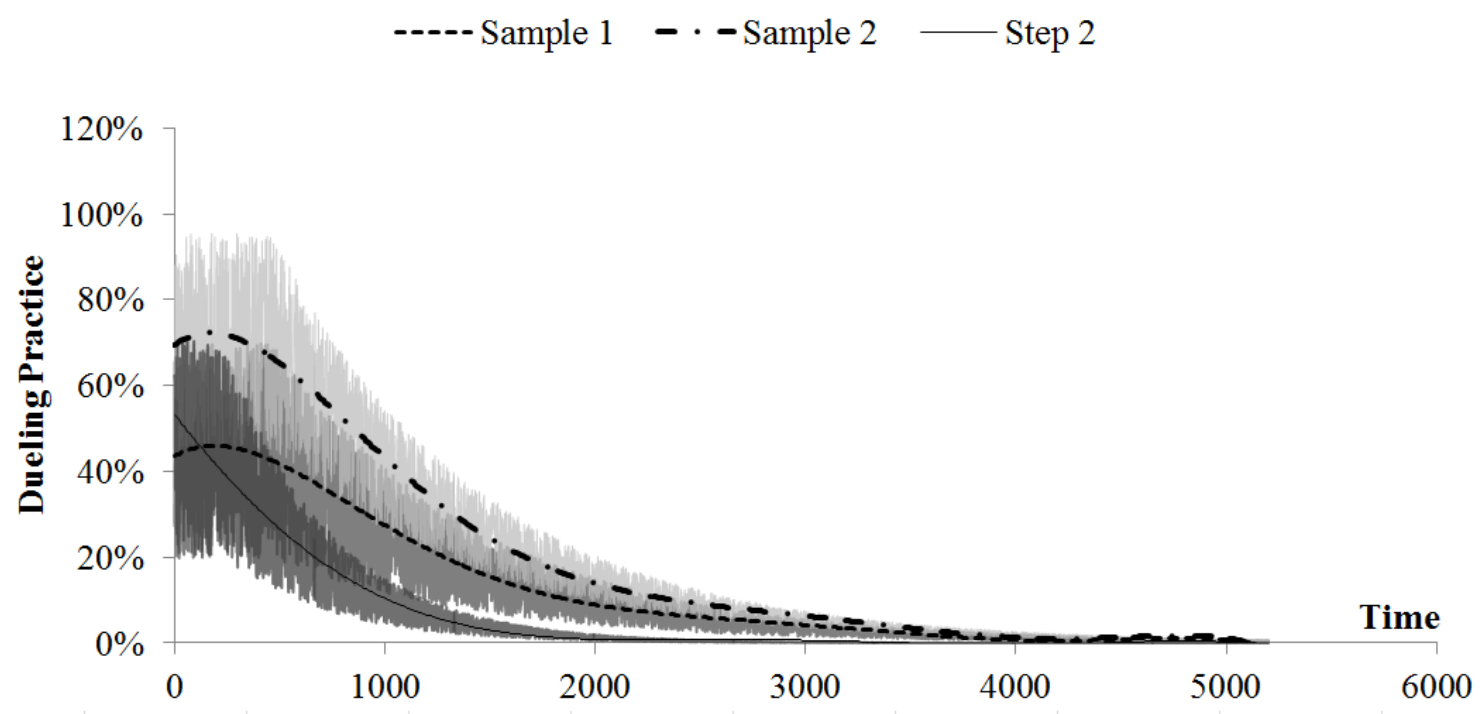

Figure 4: Results including identity and authority. The solid line represents a case in which state and military authority almost neutralize each other, and so the results are similar to those observed in Step 2. The dashed and dotted line represent cases with higher levels of military authority.

As discussed above, we have separated lethal and non-lethal dueling here to determine whether it is possible to investigate their patterns individually. Now, the question is, how much do lethal and non-lethal dueling contribute to the results shown in Figure 4 (e.g., Sample 1)? Figure 5 decomposes the total dueling trend into lethal and non-lethal trends. 


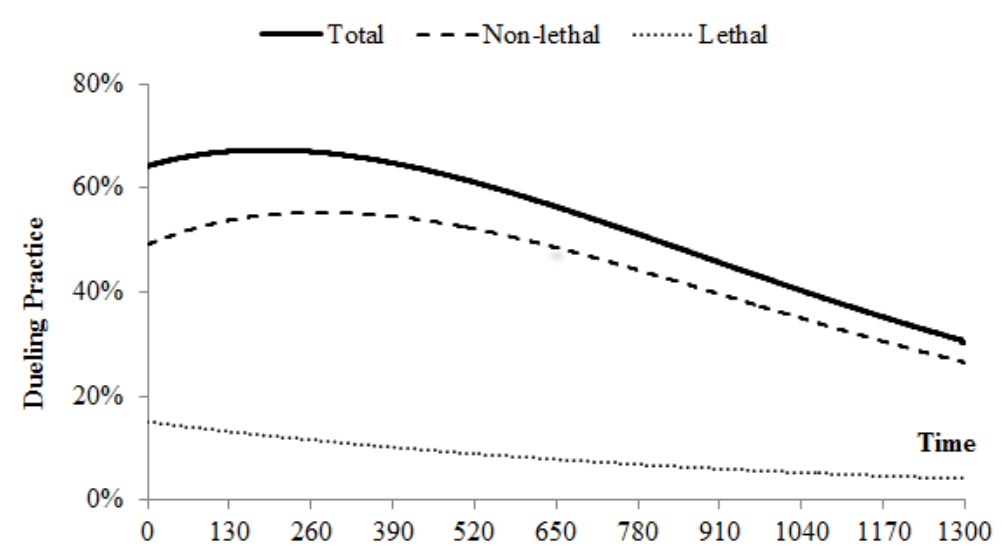

Figure 5: The trends of overall, lethal, and non-lethal dueling for a sample in Step 3

Figure 5 shows that while lethal dueling quickly disappears from the model, non-lethal dueling initially increases slightly. This is due to the fact that some agents witness how lethal duelers lose their life, so they abandon lethal dueling: consequently, their choice set shrinks from (Withdraw, Lethal, Non-lethal, Court) to (Withdraw, Non-lethal, Court).

\section{Step 4: Embourgeoisement}

Along with the identity and authority components discussed in Steps 2 and 3, which mainly affect the decision to duel among aristocrats and officers, some historical evidence suggests that dueling was widely practiced by other social groups. Some historians have referred to the adoption of the duel of honor among the middle class as 'duel's embourgeoisement.' Through this process, the 'limited access' of the aristocracy to a particular intangible asset - 'honor' - was gradually converted into an 'open access' asset.

The term 'embourgeoisement' (gentrification) was initially coined by Weberian Frevert (1995) ${ }^{24}$ to characterize the social nature of the duel of honor in Germany as a 'middle-class' institution during the nineteenth century. The expression was also used by Nye $(1993,133)$ to describe the duel's status in nineteenth century France. Frevert formulated the concept of duel's embourgeoisement to counter Marxist Kiernan, who argued that the modern European duel was the last stronghold of aristocratic privilege against the invasion of mass industrialized society represented by an ascending middle class. Kiernan labeled dueling in the nineteenth century as "the phantom virtue of a bygone era" (1988, p. 274). The debate between Frevert and Kiernan focused on the social nature of dueling

\footnotetext{
${ }^{24}$ Fervert's professorial dissertation on dueling was submitted for publication in 1989, published in Berlin in 1991 and translated into English by Anthony Williams in 1995. We refer to this English translation.
} 
during its evolution in the nineteenth century, particularly in the second half of the century. Frevert questioned Kiernan's thesis by raising a few preliminary questions: Who dueled with whom? Why? Did the social strata, which supported dueling, change during the processes of social change? Which institutions, political parties, or groups supported dueling and which tried to restrict or forbid it? According to Frevert, the central question of whether the duel of honor in the nineteenth century was merely a relic of the feudal era or whether it was a middle-class institution could not be answered without tackling these preliminary issues.

Frevert referred to the large numbers of middle-class duelers and advocates of dueling, such as Max Weber, Heinrich Simon, Heinrich Heine, and Ferdinand Lassalle, and questioned the assumption that German middle class had a strong inclination to incorporate dueling, originally the privilege of the aristocracy, into their own way of life. She argued against the validity of such an assumption based on the proven anti-aristocratic stance adopted by these men: "it is at least doubtful whether it is possible to interpret this fact as a drive towards feudalization on the part of the middle class" (Frevert, 1995, p. 7).

Accordingly, she suggested the concept of duel's embourgeoisement instead of the 'feudalization' of German's bourgeoisie. ${ }^{25}$ Blackbourn supported Frevert's argument, acknowledging that it "shows that those German bourgeois who engaged in duels were not simply imitating aristocratic norms; the meaning of the duel for middle-class Germans was shaped by the place it occupied within a specifically bourgeois code of honor" (1991, p. 14).

At this point, a new variable can be introduced to embed the concept of embourgeoisement into the model. This variable, $P_{\text {imit }}$, ranges between 0 and 1 indicates the likelihood of a non-aristocrat civilian imitating the dueling behavior. The variable can be accommodated within the model by updating the values listed in Table 10, as shown in Table 11. These changes will ensure that civilians who duel are be less likely to be punished by the state.

Table 11: Changes in the utility coefficients to accommodate embourgeoisement

\begin{tabular}{|l|l|l|}
\hline & Civilian & Officer \\
\hline Duel (lethal or non-lethal) & $\beta_{1}=P_{\text {imit }}-\tau$ & $\beta_{1}=-\tau$ \\
& $\beta_{2}=0$ & $\beta_{2}=1$ \\
\hline Court & $\beta_{1}=0$ & $\beta_{1}=0$ \\
& $\beta_{2}=0$ & $\beta_{2}=-\tau$ \\
\hline
\end{tabular}

\footnotetext{
${ }^{25}$ For a detailed analysis of this concept, see Kocka (1993).
} 
Because changes in $P_{\text {imit }}$ have significant effects on the modeled results, we next test three different models to demonstrate how embourgeoisement may have long-term effects on the likelihood of dueling.

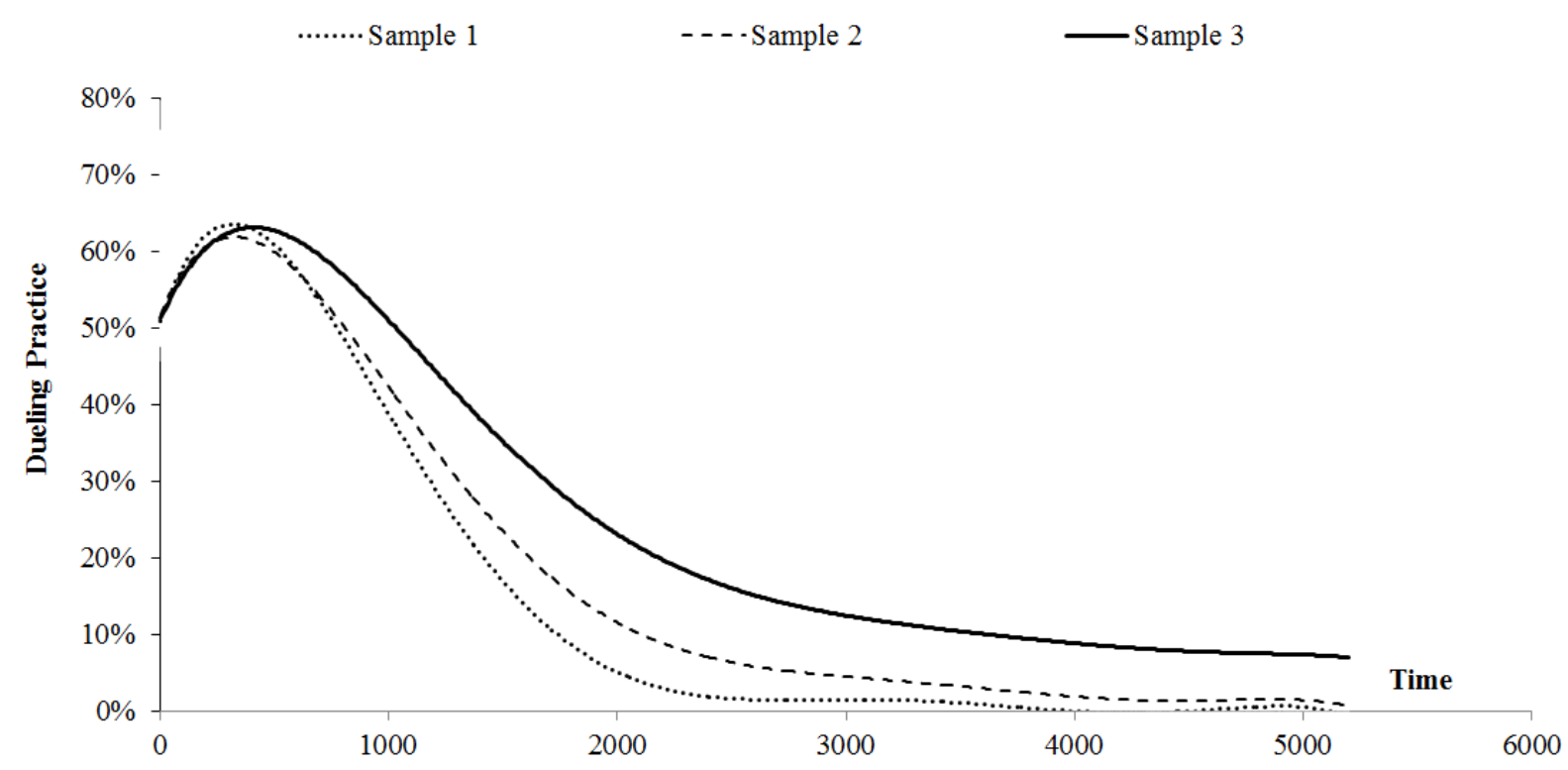

Figure 6: Dueling with low (Sample 1), medium (Sample 2), and high (Sample 3) levels of imitation probability

These results demonstrate that while low or even moderate values of imitation do not affect the model substantially, as shown in Sample 3 (solid line), a high probability of imitation can make dueling so popular that it persists at a significant level.

\section{Model Validation}

To validate these results, we ran the model based on three scenarios derived from historical evidence and assessed whether the modeled results matched the historical trends. Specifically, the three scenarios involved the evolution of dueling in England, France, and Germany.

\section{English case: Duel as undesired anarchy}

During the early Tudor period, England had a dual military system: one quasi-feudal, composed of private aristocratic armies; and the other national, under the auspices of the Crown. The greatest achievement of the Tudors was shifting the structure of power from the Lords to the Crown and the Commons (Stone, 1965). This shift meant a royal monopoly on violence, both public and private. However, even during the reign of Elizabeth I, this monopoly was far from complete and the monarchy needed to balance rival factions to avoid the constant menace of aristocratic civil war. 
Within this context, dueling was a better option than blood feuds, because it was more effective at regulating violence than the authority of the central government.

Dueling was thus an inevitable vice, because it was a leveler between upper and lower aristocracy. In the eyes of the Crown and nobility, it represented undesired anarchy and an infringement on the hierarchy of rank. The Crown was not alone in viewing dueling as undesired anarchy; the revolutionaries, Cromwell and his army, shared this view because dueling was against the law and the state. "In England, where Puritanism, capitalism, free enterprise and freedom of thought were important in a society which was otherwise very hierarchical, only isolated and more or less antisocial individuals felt the need to fight duels. The English revolutionaries were not duelers because duelers are rebels" (Billacois, 1990, 32). After the adoption of the Magna Carta, collective action of the English ruling classes was instituted in the name of law. Magistrates and laws were central to English political thought from the time of the Tudors onwards. The state was so distinct from the holders of power that Charles I could be tried and condemned to death for High Treason in January 1649. "The King was perceived more as a magistrate than as the first among gentlemen" (Billacois, p. 31), which explains why the revolutionaries justified their insurrection in the name of law. Surely, the tendency to absolute monarchy or ruling without parliament was not rare among English Kings (Sharpe, 1992, p. 603). In fact, Charles ruled England without a Parliament during eleven years before his imprisonment; a period known as the personal rule or "the eleven years' tyranny" (Carlton, 1995, pp. 153-154; Sharpe, 1992, p. xv). However, as Starkey (2006, p. 104) noted, even during this period parliament, could legally raise taxes, and without it Charles's capacity to acquire funds for his treasury was limited to his customary rights and prerogatives.

The industrial revolution and the early rise of the industrial bourgeoisie in England gave this class a far more intransigent faith in its own ways and ideas than the previous capitalist class, mercantile or financial. Earlier versions of the bourgeoisie found it natural to gravitate toward aristocracy, but later versions had a collective identity, represented by the liberalism of the Manchester school ${ }^{26}$ and the anti-corn law movement led by Cobden and Bright. Early industrialization saved the English industrial bourgeoisie from subsequent workers' movements because the bourgeoisie did not need to unite with the aristocracy against the working class (Lang, 1999). At the zenith of industrial

\footnotetext{
${ }^{26}$ Andrew (1980) argues that the replacement of the 'code of honor' by a 'code of Christian commerce' in the middle of the nineteenth century was the outcome of a growing self-confidence and self-awareness of the English middle classes.
} 
capitalism, the bourgeoisie allied with the working class against the landed aristocracy. In England, the bourgeoisie could only get its real representative, Bright, into the government by an extension of the franchise (Acemoglu and Robinson, 2005). Along with its increasing economic power, the English bourgeoisie gained increasing political power. It indirectly shared political power with the aristocracy, through its influence on the Crown and its direct participation in the Parliament, but the capital importance of law and magistrates and the strength of parliamentary institutions helped control the army's political influence. Consequently, the rising bourgeoisie was not threatened with exclusion from power.

The army, the second chief stronghold of dueling, was never overinflated in England despite its great prestige after its victories over Napoleon. The army actually had much less of an impact on society than in Germany, especially Prussia (Frevert, 1993). Moreover, in England, the second influential anti-dueling association was founded by the active participation of 35 generals and admirals in 1843 (Baldick, 1965, p. 113).

The embourgeoisement of dueling did not occur in England for two reasons: first, the semiconstitutional monarchy had strong parliamentary institutions and a relatively small and lawabiding army; and second, the early industrial bourgeoisie had a collective identity that was unthreatened by the working class and confident in its increasing economic and political power. Under such circumstances, dueling could only be tolerated insofar as blood feuds were still a menace; it remained an undesired form of anarchy with regard to order and law. The economic domination of the bourgeoisie under a state of law did not leave any room for this social institution, which was extinct by 1852. Abandonment of the duel was a clear sign of the approaching demise of the decadent aristocracy in England. Less than a generation later, the sharp decline of land rents from the 1870s onward completed its suppression by a very mixed plutocracy (Kiernan, 1988).

The emergence of dueling in England curbed blood feuds and contributed to more regulated and restricted violence. Because the aristocracy and the army were bound to respect the state and laws, they could not prolong dueling beyond a certain level of maturity of the new order. Contradictory orders had a relatively short historical period; they were dissolved and gave way to the rule of law.

\section{French case: Dueling as desired anarchy}

As discussed in the previous section, only the French recklessly engaged in duels after the third quarter of the sixteenth century. They embraced dueling with such ardor that no other country matched the French levels of death from dueling. In France, dueling first emerged among poor, 
rootless, and aggressive gentry and petty nobility, many of whom had served on either side during the Thirty Years' War (Billacois, 1990, p. 24). This schism of the French population between two faiths, Catholics and Protestants (which was aggravated by civil wars), ${ }^{27}$ and the French path to absolute monarchy, were two reasons why dueling was embraced so vigorously in France.

As the Revolution approached, aristocracy and haute mercantile and financial bourgeoisie increasingly mingled. Their sense of fraternity and equality grew to the point that they could challenge each other freely: even men without coats of arms could challenge or be challenged to a duel (Kiernan, 1988). Dueling in France was a desired anarchy both for aristocrats and the middle classes; it represented a libertarian individualist anarchism and acted as a leveler. Carlyle (1837) referred to this leveling effect of dueling, "[A]11 Frenchmen have the 'right of duel'; the Hackneycoachman with the Peer, if insult be given! Such is the law of Public Opinion. Equality at least in death!" The duel was a flexible or imitable tradition in France and lasted longer than in England due to its embourgeoisement.

Unlike the English aristocracy, the French nobility adapted to the duel's embourgeoisement during the Restoration period. In contrast to the British Code of Duel ${ }^{28}$, the publication of a new code of dueling in 1836 by the Comte de Chatauvillard and countersigned by men representing France's most illustrious families, including 11 Peers and the cream of the military elite (Jeanneney, 2004, p. 78) facilitated the duel's embourgeoisement. The widespread acceptance of this new code, Essai sur le duel, the first of its kind since the seventeenth century, contributed largely to the predominance of a non-lethal type of dueling known as the 'first-blood duel' (duel au premier sang). First-blood duels were necessarily fought using swords, and as Chatauvillard wrote, "in the present state of our manners, an ordinary duel (au premier sang) suffices the noble need to expunge an offense" (1836, p. 122). He claimed that he was publishing this code because he regarded it as his "humanitarian duty to modernize and regularize a practice that was a necessary and inevitable feature of civilized life" (Nye, 1993, p. 137). The predominance of first-blood duels is clearly reflected in the rise of épée dueling, which explains the popularity of fencing: "Politicians, journalists, writers and businessmen -men in high risk categories- frequented the fencing halls to learn basic technique and stay fit" (Nye, 1990, p. 371). Comte de Chatauvillard's code of dueling, and the French

\footnotetext{
${ }^{27}$ Billacois (1990) documented how in France, duels flourished as society was breaking into rival groups of Catholics and Protestants.

28 The British Code of Duel recommended in 1824 that, before a duel was arranged, it should be established that "both parties belonged to the class of gentlemen" (Frevert, 1993, p. 221).
} 
aristocracy's adaptation to the idea of modernizing the duel, were major sources of duel's embourgeoisement in France. ${ }^{29}$

Some statistics for the first half of the century are available from the French Ministry of Justice, Tarde (1892), and Chesnais (1981), and Nye (1990,1993) compiled a master inventory of duels that occurred between 1860 and 1914 from a number of sources. The numerous shortcomings of these data notwithstanding, ${ }^{30}$ they provide a general picture of the embourgeoisement of dueling. Table 12 documents the evolution of dueling from 1819-1900 with respect to the frequency and lethality of duels. According to Chesnais (1981), more than 832 deaths were recorded in the army, or more than 100 duels annually, from 1819-1826. From 1826-1834, the number of total deaths decreased by two-thirds, to 228 (Tarde's estimate for this period was 189 deaths; see Tarde, 1892). After 1835 , the average number of duels per year declined to 100 (Nye, 1990), and the lethality rate also decreased from an initial rate of one-third (33\%) to approximately 6\% (3 deaths over 53 combats) in the 1870s (Chesnais, 1981, p. 109). From the 1880s until well into the 1900s, the frequency of dueling increased rapidly, peaking at 400-500 duels per year (Nye, 1990, p. 371). Tarde's estimate of 60 duels per year in the 1880s is far too low; based on Nye's conservative estimates, the average might be 200 duels per year from 1875-1900, and as late as 1911 as many as 5 duels took place in Paris alone over a period of 20 days (Nye, 1993, p. 185).

Table 12: Evolution of dueling in France from the early nineteenth century until the First World War

\begin{tabular}{|l|l|l|l|l|}
\hline Period & $\mathbf{1 8 1 9 - 1 8 2 6}$ & $\mathbf{1 8 2 7 - 1 8 3 4}$ & $\mathbf{1 8 3 5}-\mathbf{1 8 8 0}$ & $\mathbf{1 8 8 0 - 1 9 1 4}$ \\
\hline Frequency per year & $>100$ & $>100$ & 100 on average & 200 on average \\
\hline Number and/or percentage of deaths & 832 & $228(33 \%)$ & $\geq 6 \%$ to $\leq 33 \%$ & $<2 \%$ \\
\hline
\end{tabular}

While the frequency of dueling increased rapidly after 1880s, lethality rates dropped drastically to less than 2\% during the period 1880-1914, according to Tarde's (1892) research based on Ferréus's Annuaire du duel.

\footnotetext{
${ }^{29}$ When Chatauvillard's code was translated into English four years later (in 1840), the English press considered it evidence of the blossoming of a 'barbarous' practice (Kiernan, 1988, p. 262).

${ }^{30}$ These deficiencies include the lack of official procès-verbaux (reports) provided by seconds during the first part of the nineteenth century due to the lack of the mass press; the paucity of information regarding duels in provinces throughout the nineteenth century, the private and unreported nature of duels; treatment of death caused by dueling as homicide (assassinat), manslaughter (meurtre), or simple aggression; and finally the absence of any exhaustive research and documentation regarding dueling in general.
} 
As shown in Table 13, only 431 of 598 arranged duels were actually fought; the rest (almost onethird) were 'shunned' thanks to the active role of conscientious seconds and in conformity with Chatauvillard's code of dueling. The total of 16 deaths from the 431 duels that resulted in combat averages to 1 death per 26 duels. The fact that the frequency of dueling doubled after the 1880s, and that non-lethal duels by épée became common, illustrate the popularity of civilian duels.

Table 13: Dueling frequency and lethality in the 1880s

\begin{tabular}{|l|l|l|l|}
\hline Duels resulting in combat & Shunned duels & $\begin{array}{l}\text { Total number of } \\
\text { arranged duels }\end{array}$ & Total number of deaths \\
\hline 431 & 167 & 598 & 16 \\
\hline
\end{tabular}

In sum, while the aristocratic duel experienced a form of potlatch destruction (Vahabi, 2011), dueling in the Third Republic was a phenomenon among 'civilized' society: Parisian journalists, politicians, and middle classes used duels to build a reputation capital.

\section{German case: Dueling as military order}

The duel was imported into Germany as a French fashion, but it never represented anarchy; it always incarnated order, particularly military order. A double standard between 'military honor' and 'civilian honor' was instituted after the Prussian Law Code of 1794: a duel could only take place between officers and noblemen; armed clashes among other civilians, including the bourgeoisie, were handled by criminal law. Civilians were thus denied treatment under the dueling statutes. In the 1820s and 1830s, the German Bürger won the right to duel, and the switch from swords to pistols facilitated his participation. As in France, the duel became bourgeois in Germany, but the army, the one undeniably non-liberal, non-bourgeois institution in Germany, remained the duel's chief procurator. ${ }^{31}$ The German army permeated civilian life in a multitude of ways and on a large scale; Frevet coined the term "social militarization" to describe this process (1995, p. 36).

Dueling blossomed in Germany especially from 1870-1914, and social militarization resulted in the longest continuation of dueling in Germany, compared with England and France.

\footnotetext{
${ }^{31}$ As long as the officer corps was recruited exclusively from the aristocracy, its honor was aristocratic. This changed with the growing recruitment of officers from the middle class. "By 1861, nearly 20 percent of higher-ranking German army officers were bourgeois; although some regiments (notably the cavalry) had managed to maintain their exclusively aristocratic composition, others (such as the engineers, artillery, or supplies) had a higher than average number of middleclass officers. By the eve of the First World War, the proportions had shifted much further in favour of the bourgeoisie. By then, as many as 48 percent of Prussian generals and colonels were middle class, while three-quarters of the majors and first and second lieutenants were of bourgeois origin. Middle-class representation was particularly high in the naval officer corps, which had only been created under the Empire and had no aristocratic tradition to look back on." (Frevert, 1991, p. 275).
} 
The double standard between civilian and military honor was maintained until the end of the nineteenth century. Max Weber alluded to this double standard when he wrote about contradictory orders. In 1848, Prince Wilhelm did not regard this coexistence of military and civilian jurisdiction as 'anarchy' - for the King of Prussia and Emperor of Germany, the "apostles of anarchy” were those individuals whose primary concern was "undermining the honor of officers" (Frevert, 1995, p. 39). Unlike in France, in Germany the duel was neither a leveler nor a rebellion against order; it was a source of military order, hierarchy, and the caste system. Dueling for the honor of officers was a moral duty rather than an act of heroic voluntarism, which explains why the code of honor was not merely a custom or a social value, but an obligation that was systematically enforced by military jurisdiction.

Because dueling symbolized Prussian order, opposition about civilian versus military honor became polarized, and this opposition continued until the end of fascism. ${ }^{32}$ After the First World War, the nature of dueling changed radically. The first contributory factor in this process was the demilitarization of Weimar society, "a phenomenon which was reflected in the creation of a small professional army with a numerically insignificant officer corps" (Frevert, 1995, p. 217). The second factor was the destabilization of the middle class during the crisis years of the Weimar Republic.

The situation changed again with the rise of National Socialism. In 1933, criminal law was changed and student duels were expressly declared exempt from punishment, but this type of dueling was non-lethal and regarded as "student sabre duels" (Frevert, op.cit., p. 219). Although this non-lethal dueling was similar to French fencing, there was one major difference: German dueling could not be individualistic: "no German had the right to shed his blood for selfish reasons" (Frevert, op.cit., p. 225). In December 1938, Hitler announced that he was reserving for himself the right to sanction duels between officers; henceforth, all duels involving party members required his approval. Throughout the Weimar Republic and the Nazi era, student dueling societies continued to exercise their influence. Despite their initial prohibition by the Allied Control Council in 1945, and a declaration issued at a conference of university vice-chancellors in October 1949, these societies succeeded in persuading the Federal Court of Justice to exempt student dueling from being a

\footnotetext{
${ }^{32}$ Fascism resurrected dueling. Mussolini revered dueling, and three years after Hitler seized power, dueling was legalized in Germany as "the ultimate means for the defense of honor: under the supervision of special tribunals. At this point, the privilege was extended to all Germans, because as a member of Herrenvolk, every German was "noble" (Kiernan, 1988, pp. 53-54). According to Coombs (1997), Hitler was personally opposed to the practice.
} 
criminal offence (Frevert, op.cit., pp. 228-29). Paragraphs involving dueling were only abrogated from the criminal code after the reform of German criminal law in 1969. 
Table 14 summarizes the three cases of dueling in England, France, and Germany

Table 14: A comparative representation of dueling in England, France, and Germany

\begin{tabular}{|l|l|l|l|l|l|l|}
\hline Country & Type of state & $\begin{array}{l}\text { Place of army and } \\
\text { parliament }\end{array}$ & $\begin{array}{l}\text { Early or late } \\
\text { industrialization }\end{array}$ & $\begin{array}{l}\text { Duel of honor: Anarchy or } \\
\text { order }\end{array}$ & $\begin{array}{l}\text { Duel's } \\
\text { embourgeoisement }\end{array}$ & $\begin{array}{l}\text { Historical duration of the } \\
\text { duel of honor }\end{array}$ \\
\hline England & $\begin{array}{l}\text { Semi- } \\
\text { constitutional } \\
\text { monarchy } \\
\text { (state of law) }\end{array}$ & $\begin{array}{l}\text { Balance of power } \\
\text { between army and } \\
\text { parliament }\end{array}$ & $\begin{array}{l}\text { Early (industrial } \\
\text { revolution) }\end{array}$ & Undesired anarchy & $\begin{array}{l}\text { Absent (sudden end } \\
\text { of dueling) }\end{array}$ & 1590-1852 \\
\hline France & Bonapartism & $\begin{array}{l}\text { Strong and active } \\
\text { army versus weak and } \\
\text { passive parliament }\end{array}$ & Intermediary & Desired anarchy & $\begin{array}{l}\text { Present (gradual } \\
\text { termination of } \\
\text { dueling) }\end{array}$ & $\begin{array}{l}\text { lethal dueling (from the second } \\
\text { half of the 16 } \\
1880 s), \text { and non-lethal until } \\
\text { century until the } \\
1918\end{array}$ \\
\hline Germany & Junker state & $\begin{array}{l}\text { A state within the } \\
\text { state } \\
\text { (social militarization) }\end{array}$ & Late & Military order & $\begin{array}{l}\text { Present (gradual } \\
\text { termination of } \\
\text { dueling) }\end{array}$ & $\begin{array}{l}\text { Gradual termination: lethal } \\
\text { dueling (from the second half } \\
\text { of the 16 } \\
\text { and non-lethal } \\
\text { century until 1918), }\end{array}$ \\
until the 1950s
\end{tabular}




\section{Experiments}

Based on the above discussions of the three cases in England, France and Germany, in this section we test whether our model can replicate these cases and simulate the trajectory of dueling, in terms of duration and intensity. Specifically, the model should show that:

1- Dueling continues for a longer period in an environment that simulates conditions in Germany compared with an environment that simulates conditions in France, and continues for a longer period in an environment that simulates conditions in France compared with an environment that simulates conditions in England.

2- Dueling gradually shifts from lethal to non-lethal and eventually disappears over time.

As discussed above, the available historical evidence cannot be quantified because no clear measure is available to represent aristocracy unity, state and military power, or the imitability of dueling over time and geographical distance. As a result, we defined a set of random values to capture not the levels, but differences between countries in terms of identity, authority, and embourgeoisement. To improve this value assignment, instead of using a single number to show, for example, the role of authority in England compared to France, we used two intervals, each following a normal distribution: if $\mu_{1}, \mu_{2}$, and $\mu_{3}$ and $\sigma_{1}, \sigma_{2}$, and $\sigma_{3}$ represent the mean and standard deviation of the left, middle and right distributions, we then have: $\sigma_{1}=\sigma_{2}=\sigma_{3}$ and $\mu_{\mathrm{i}}-\mu_{\mathrm{i}-1}=\sigma_{1}$. We also ran the models under $\mu_{\mathrm{i}}-\mu_{\mathrm{i}-1}=2 \sigma_{1}$ and $\mu_{\mathrm{i}}-\mu_{\mathrm{i}-1}$ $=3 \sigma_{1}$ for verification purposes. Table 15 presents the selected initial conditions for each case.

Table 15: The applied values to simulate the differences between features of each country in terms of factors associated with dueling

\begin{tabular}{|l|l|l|l|l|l|}
\hline \multicolumn{7}{|l|}{ Case-specific Values } \\
\cline { 2 - 6 } & s.d. Aristocracy & $P_{\text {state }}$ & $P_{\text {military }}$ & $P_{\text {imit }}$ & IS/IO \\
\hline England & $\mathrm{N}(0.25,0.05)$ & $\mathrm{N}(0.70,0.1)$ & $\mathrm{N}(0.60,0.1)$ & $\mathrm{N}(0.10,0.05)$ & $\begin{array}{l}\mathrm{N}(0.70, \\
0.1)\end{array}$ \\
\hline France & $\mathrm{N}(0.15,0.05)$ & $\mathrm{N}(0.60,0.1)$ & $\mathrm{N}(0.50,0.1)$ & $\mathrm{N}(0.20,0.05)$ & $\begin{array}{l}\mathrm{N}(0.55, \\
0.1)\end{array}$ \\
\hline Germany & $\mathrm{N}(0.15,0.05)$ & $\mathrm{N}(0.60,0.1)$ & $\mathrm{N}(0.70,0.1)$ & $\mathrm{N}(0.20,0.05)$ & $\begin{array}{l}\mathrm{N}(0.55, \\
0.1)\end{array}$ \\
\hline
\end{tabular}

Based on the historical evidence, the model is set such that:

1. England has less aristocracy unity than France and Germany, which have similar unity levels. This distribution shows the standard deviation of aristocracy. 
2. State power is higher in England than both France and Germany, which have similar values.

3. Military power is higher in Germany than in France or England.

4. Imitation is lower in England than in France or Germany.

5. Dueling is a more important component of aristocratic identity in England than in France and Germany.

Figure 7 presents the dueling trends across three countries during the simulation. While the model generated the correct order of disappearance of dueling across the three countries, the time scales were not accurate. This was mainly due to the fact that we did not include the many other country-specific variables (e.g., interstate conflicts or intrastate wars, and other social, economic, or cultural factors) that may contribute to the dynamics of dueling. The model also yielded more variations in the case of Germany, while it yielded similar levels of volatility for England and France.

Figure 8 decomposes trend in terms of lethal versus non-lethal dueling. As in the real-world cases, the simulations first substituted lethal dueling with non-lethal dueling, and then both patterns disappeared.

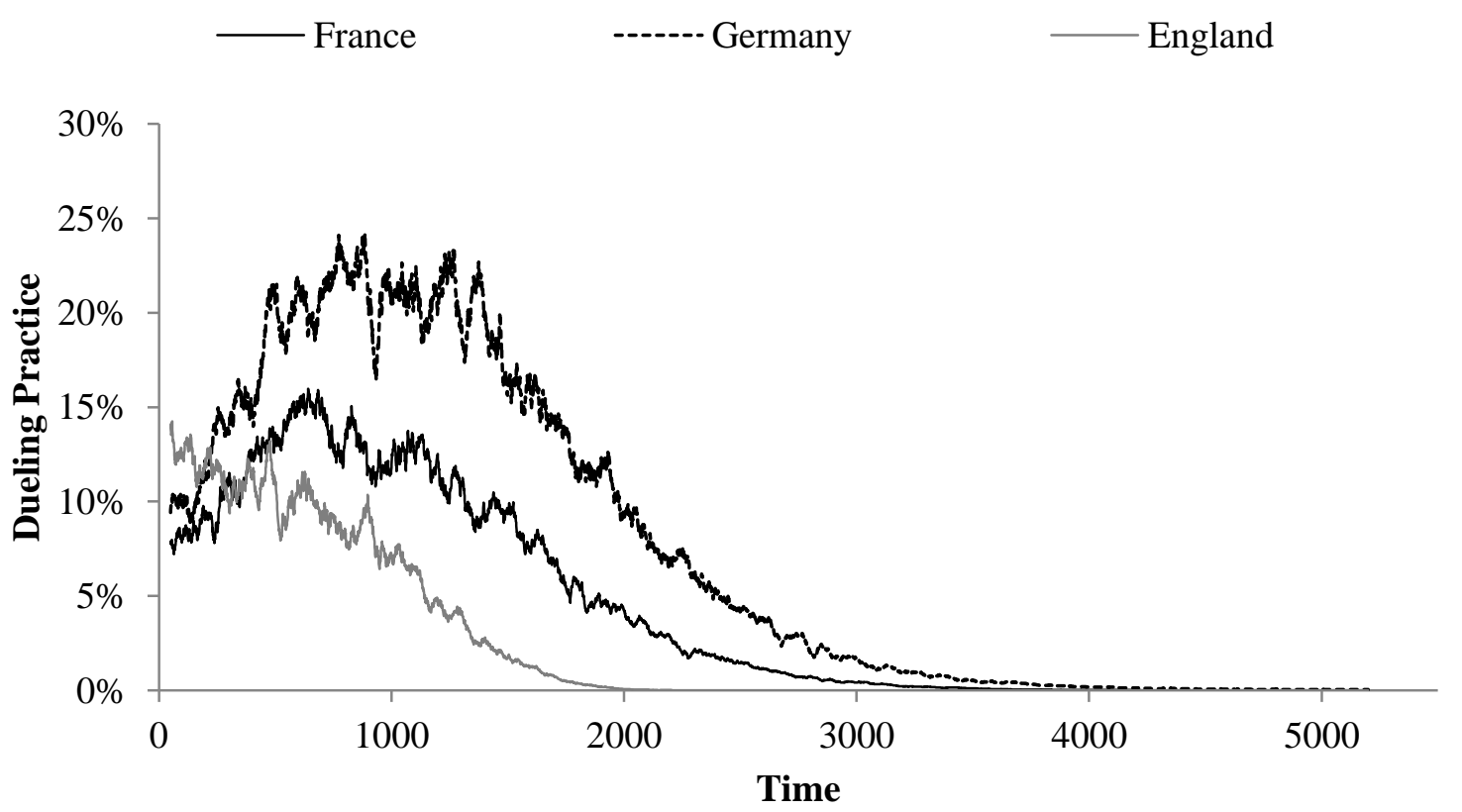

Figure 7: Durations of dueling in the three simulations. 


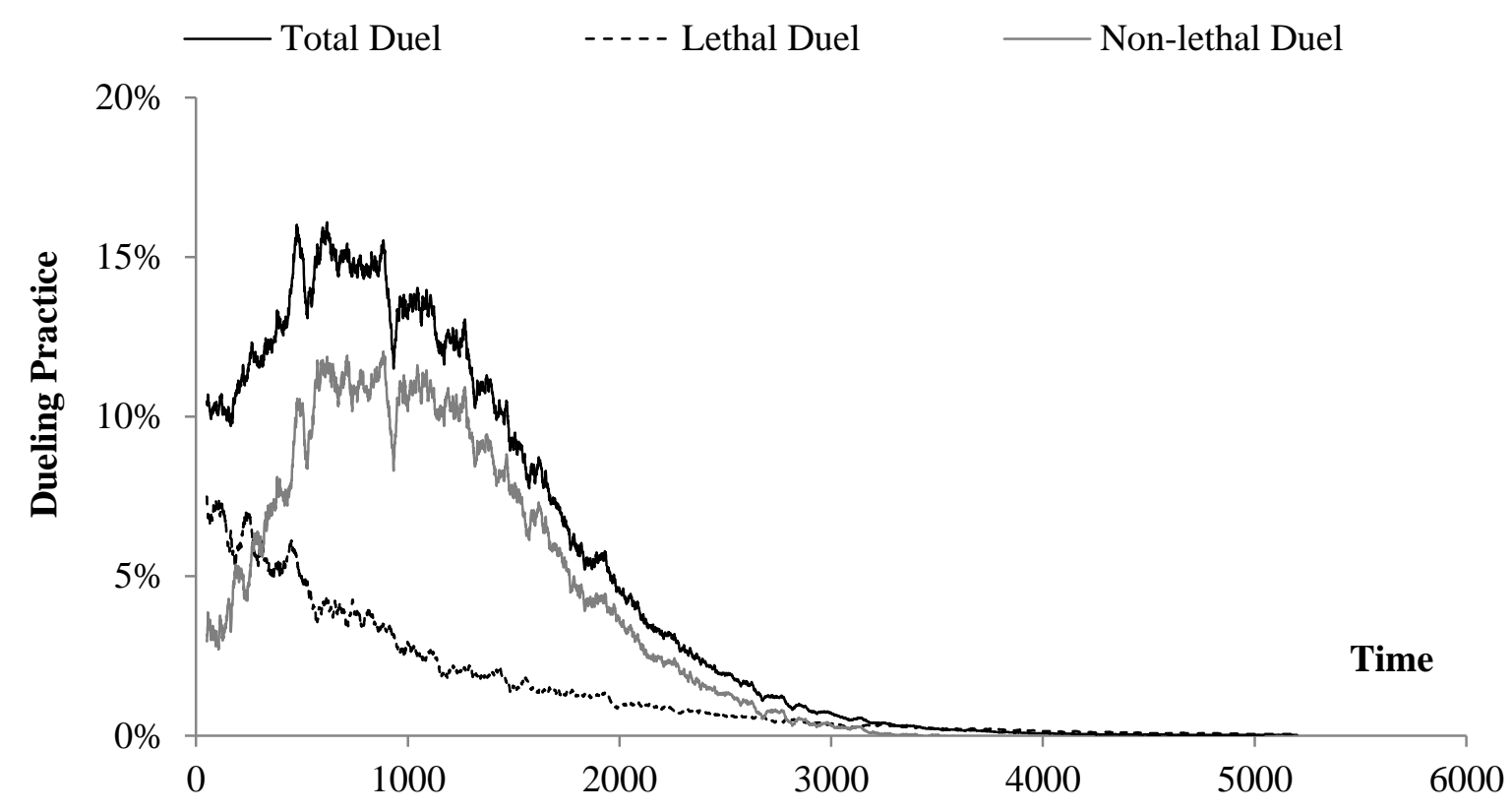

Figure 8: Decomposing dueling trend to lethal and non-lethal patterns.

\section{Conclusions}

In their frequently cited paper, Einstein et al. (1935) proposed two questions to deem the success of a physical theory: 1) Is the theory correct?, and 2) Is the description given by the theory complete? They argued that in the field of physics, the correctness of a theory can be assessed by comparing what the theory concludes and what humans experience through experiment and measurement, while the condition of completeness is satisfied if "every element of physical reality has a counterpart in the physical theory".

In the social sciences, taking into account all the possible 'elements' of a system may seem impossible. Here, we have attempted to show how, following Tullock and other scholars, moving toward a more complete model of a public choice system can yield more accurate results and a better understanding of how the system works and evolves when exploring possible links between economics and politics.

To our knowledge, this paper is the first to provide a comprehensive theory about the main factors that encouraged or discouraged dueling, including individual preference, network effects, the role of identity, responses from authority, and finally imitation probability. 
To test the validity of our design, we developed an agent-based model, capable of taking into account different factors and their possible complex interactions, to explore the dynamics of the duel of honor in Europe. The results over the various simulation steps, and the validation outcomes, demonstrated that the introduced components are, to some extent, successful in explaining the intensity (lethal and non-lethal) and duration of dueling across the case studies.

The ability of an agent-based model to replicate the historical emergence and evolution of dueling as an institution in England, France, and Germany has significant implications. It demonstrates that a complex, aggregative historical process may be consistently explained on the basis of rational choice of heterogeneous individual agents, conditioned by group identity and authority. Our study identified four principal sources of anarchy and order that have major policy implications.

First, as the first step of our model demonstrated, rational calculation of homo oeconomicus supports order. In this sense, Weber (1968) is correct in considering rationality as a source of legitimacy of the state order in his tripartite classification of authority. Market relationships enhance legal rationality. This explains why duel of honor ended suddenly in the middle of the nineteenth century in England as an early industrialiser, before any other European country. By contrast, duel of honor withered away through a long and incremental process of 'embourgeoisement' in late industrialisers like France and Germany. The 'malleability of identity' or the gradual change of preference was a way to transform duel from a lethal confrontation to a non-lethal one. The fact that duel was adopted on a mass scale resulted in 'rationalizing' duel, transforming it into a non-lethal, less costly method of settling disputes.

Second, while anarchy is the absence of state enforcement, a strong army is not a condition of transition to order. In fact, a strong army may be a source of anarchy, since the military caste might be motivated to consider itself beyond law. As the examples of France and Germany illustrate, a stronger position of the army in the state provides a fertile soil for the prolongation of duel of honor by breeding contradictory orders in which a military caste maintains 'aristocratic' privileges of acting as enforcers of its own rules and laws above the state law. This type of anarchy may be coined as 'anarchy from above'. By contrast, a state of law in which the army is not stronger than parliament and legislative power furnishes the foundation of order. 
Third, strong inequalities in having access to productive resources may incentivize anarchy as a leveler: equality in death is an approximate substitute for inequality in life. France was the birthplace of duel of honor as a leveler. This type of 'desired anarchy' can be named as 'anarchy from below' since it is supported by people of lower social ranks as a means of leveling social inequalities. Contrarily to France, rebels and revolutionaries in England were advocates of a state of law, since the rules of law were not only considered to be as an accepted pact among 'gentlemen' but also a benchmark of right conduct by commoners.

Fourth, while we underlined the importance of social identity in understanding individual behavior, it is noteworthy that duel of honor is perhaps one of the early manifestations of individualism in the early modernity. Indeed, individualism was expressed in three different forms in Europe. In England, individualism manifested itself in terms of economic 'selfinterest'. Adam Smith's invisible hand is a reflection of this economic type of individualism which is in tune with legal rationality. In France, individualism expressed itself in the name of individual political freedoms. Duel of honor was an early echo of French political individualism. Dueling lasted longer in France than England, since the French perceived it as 'libertarian individual anarchism', a liberation from tyranny and a leveler with aristocrats. In Germany, individualism was rather philosophical and might be traced back to philosophical works of Fichte, Schelling and Kant; but duel of honor was not an expression of individualism stemming from a selfish amour proper. It reflected tribal egotism, or male individual moral duty to his social group/rank. In Germany, lethal dueling lasted longer than France because of its egotist nature. Accordingly, the persistence of anarchy is not only dependent on the formal rules (lack of state enforcement) but also the way anarchy is informally perceived in the society. After the Industrial Revolution, duel of honor lost its value as a reputation capital in England. By contrast, in France and Germany, dueling was an identity investment until the outbreak of the First World War. The total war changed people's attitude towards violence and shaped another social norm according to which violence as a means of resolving disputes was now regarded as barbarous and uncivilized. Norbert Elias was among the first social thinkers who noticed this point: "The terms gradually die when the functions and experiences in the actual life of society cease to be bound up with them. At times, too, they only sleep, or sleep in certain aspects, and acquire a new existential value from a new social situation" ([1937]2000, pp. 8-9). 
Other sources of anarchy and order should be explored by analyzing recent cases of political transitions involving violent conflicts. In our opinion, our analysis of the evolution of order, and the roles of identity and authority in shaping economic and political phenomena, can be applied to clarify the dynamics of developing and emerging countries with failed states, where the state does not have a monopoly on violence and different elite groups manage conflict resolution in a self-regulatory way. This theory and model can be further improved by taking into account more case studies, and also by adding some country-specific issues to explain other aspects of the duel of honor. In the future, it should also encourage public choice scholars as well as institutionalists to use computational methods to analyze real-world systems.

\section{Acknowledgments}

An earlier version of this paper has been presented at the Meeting of European Public Choice Society (EPCS), Zurich, April 3rd to 6th, 2013. We benefited from the comments of the participants of the afore-mentioned scientific manifestation in preparing the present version of our paper. We would like to thank two anonymous referees and the editors of Economic Modelling for their inspiring and insightful remarks. Obviously, all the remaining errors are ours. Mehrdad Vahabi dedicates this paper to Eric Coriolat for their common memories.

\section{References}

Acemoglu Daron and James Robinson. 2001. "A Theory of Political Transitions”, American Economic Review, Vol. 91, No. 4, September, pp. 938-963

Akerlof, G. A., \& Kranton, R. E. 2000. "Economics and identity". Quarterly journal of Economics, 715-753.

Acemoglu, Daron and Robinson, James. 2005. Economic Origins of Dictatorship and Democracy, Cambridge: Cambridge University Press.

Acemoglu, Daron and James Robinson. 2008. "Persistence of Power, Elites, and Institutions”, American Economic Review, Vol. 98, No. 1, March, pp. 267-293.

Akerlof, George A, and Rachel E Kranton. 2010. Identity economics: How our identities shape our work, wages, and well-being: Princeton University Press.

Akerlof, George A., and Rachel E. Kranton. 2000. "Economics and Identity." The Quarterly Journal of Economics no. 115 (3):715-753. doi: 10.1162/003355300554881.

Allen, Douglas W. and Clyde G. Reed. 2006. "The Duel of Honor: Screening For Unobservable Social Capital”, American Law and Economics Review, Vol. 8, pp. 81-115. 
Andrew, Donna T. 1980. "The code of honour and its critics: the opposition to dueling in England, 1700-1850." Social history no. 5 (3):409-434.

Baldick, Robert. 1965. The duel : a history of dueling. London: Chapman \& Hall.

Billaçois, François. 1990. "The duel: its rise and fall in early modern France, trans." Trista Selous (New Haven, 1990).

Blackbourn, David. 1991. "The German bourgeoisie: an introduction." In The German bourgeoisie: essays on the social history of the German middle class from the late eighteenth to the early twentieth century, edited by David Blackbourn and Richard J Evans, 1-45. Routledge.

Boulding, Kenneth Ewart. 1962. Conflict and defense: A general theory. Vol. 3024: Harper New York.

Buchanan, James McGill, and Robert D Tollison. 1984. The Theory of Public Choice: II: University of Michigan Press.

Bush, W. C., \& Mayer, L. S. 1974. "Some implications of anarchy for the distribution of property." Journal of Economic Theory, 8(4), 401-412.

Carlton, Charles, 1995, Charles I: The Personal Monarch (Second ed.), London: Routledge.

Chesnais, Jean-Claude. 1981. Histoire de la violence en Occident de 1800 à nos jours: R. Laffont.

Clark, Derek J, and Christian Riis. 1998. "Contest success functions: an extension." Economic Theory no. 11 (1):201-204.

Cockburn, John. 1720. The History and Examination of Duels: G. Strahan, R. Knaplock, R. Goslin, W. Lewis, T. Harbin, W. Graves, and B. Barker.

Demeter, Karl. 1965. The German officer-corps in society and state, 1650-1945: Weidenfeld and Nicolson.

Dosi, Giovanni, Giorgio Fagiolo, and Andrea Roventini. 2009. "The microfoundations of business cycles: an evolutionary, multi-agent model." In Schumpeterian Perspectives on Innovation, Competition and Growth, 161-180. Springer.

Dosi, Giovanni, Giorgio Fagiolo, and Andrea Roventini. 2010. "Schumpeter meeting Keynes: A policy-friendly model of endogenous growth and business cycles." Journal of Economic Dynamics and Control no. 34 (9):1748-1767.

Einstein, Albert, Boris Podolsky, and Nathan Rosen. 1935. "Can quantum-mechanical description of physical reality be considered complete?" Physical review no. 47 (10):777.

Elias, Norbert, [1937]2000, The Civilizing Process, Sociogenetic and Psychogenetic Investigations, Oxford, Blackwell Publishers.

Epstein, Joshua M. 2002. "Modeling civil violence: An agent-based computational approach." Proceedings of the National Academy of Sciences of the United States of America no. 99 (Suppl 3):7243-7250.

Epstein, Joshua M. 2006. "Chapter 34 Remarks on the Foundations of Agent-Based Generative Social Science." In Handbook of Computational Economics, edited by L. Tesfatsion and K. L. Judd, 1585-1604. Elsevier. 
Frevert, Ute. 1991. "Bourgeois honor: middle-class duelers in Germany from the late eighteenth to the early twentieth century." In The German bourgeoisie: essays on the social history of the German middle class from the late eighteenth to the early twentieth century, edited by David Blackbourn and Richard J Evans, 255-292. Routledge.

Frevert, Ute, and Anthony Williams. 1995. Men of honour: a social and cultural history of the duel: Polity Press Cambridge, MA.

Gagné, Learry. 2007. "Non-rational compliance with social norms: sincere and hypocritical", Social Science Information, Vol. 46, No. 3, pp. 445-469.

Garfinkel, Michelle R., and Stergios Skaperdas. 2007. "Economics of Conflict: An Overview." In Handbook of Defense Economics: Defense in a globalized world, edited by Todd Sandler and Keith Hartley. Elsevier.

Guillet, François. 2007. "L'honneur en partage. Le duel et les classes bourgeoises en France au XIXe siècle." Revue d'histoire du XIX siècle (1):55-70.

Guillet, François. 2008. La mort en face: histoire du duel de la Révolution à nos jours: Aubier.

Haferkamp, Hans, and Neil J. Smelser. 1992. Social change and modernity. Berkeley. University of California press.

Hassani-Mahmooei, Behrooz, and Brett W Parris. 2013. "Resource scarcity, effort allocation and environmental security: An agent-based theoretical approach." Economic Modelling no. 30:183-192.

Heckbert, Scott, Tim Baynes, and Andrew Reeson. 2010. "Agent-based modeling in ecological economics." Annals of the New York Academy of Sciences no. 1185 (1):39-53. doi: 10.1111/j.1749-6632.2009.05286.x.

Hirshleifer, Jack. 1989. "Conflict and rent-seeking success functions: Ratio vs. difference models of relative success." Public Choice no. 63 (2):101-112.

Holland, John H. 1992. "Complex Adaptive Systems." Daedalus no. 121 (1):17-30.

Jeanneney, Jean-Noël. 2004. Le duel-Une passion française: Paris, Le Seuil.

Kiernan, Victor Gordon. 1988. The duel in European history: honour and the reign of aristocracy: Oxford University Press New YorkOxford.

Kingston, Christopher G, and Robert E Wright. 2010. "The deadliest of games: the institution of dueling." Southern Economic Journal no. 76 (4):1094-1106.

Kirman, Alan P, and Nicolaas J Vriend. 2001. "Evolving market structure: An ACE model of price dispersion and loyalty." Journal of Economic Dynamics and Control no. 25 (3):459502.

Konrad, Kai A. 2009. "Investing in regimes with stationary or roving bandits." In Guns and Butter: The Economic Causes and Consequences of Conflict, edited by Gregory D. Hess, 121. Cambridge, Mass: MIT Press.

Kooreman, Peter, and Lambert Schoonbeek. 1997. "The specification of the probability functions in Tullock's rent-seeking contest." Economics Letters no. 56 (1):59-61. 
Kurisu, Tadashi. 1983. "Two-noisy-versus-one-silent duel with equal accuracy functions", Journal of Optimization Theory and Applications, Vol. 39, pp. 215-35.

Kurisu, Tadashi. 1991. "On a duel with time lag and arbitrary accuracy functions", International Journal of Game Theory, Vol. 19, pp. 375-405.

Lang, Sean. 1999. Parliamentary Reform, 1785-1928. New York: Routledge.

LeBaron, Blake, and Leigh Tesfatsion. 2008. "Modeling macroeconomies as open-ended dynamic systems of interacting agents." The American Economic Review no. 98 (2):246-250.

Leeson, P. T. 2009. “The laws of lawlessness". The Journal of Legal Studies, 38(2), 471-503.

Leeson, Peter T. 2011. "Trial by battle." Journal of Legal Analysis no. 3 (1):341-375.

Leeson, P. T., \& Williamson, C. R. 2009. "Anarchy and development: an application of the theory of second best". The Law and Development Review, 2(1), 77-96.

Liu, Y. F., Zhang, W., \& Xu, H. C. 2014. "Collective behavior and options volatility smile: An agent-based explanation". Economic Modelling, 39, 232-239.

McAleer, Kevin. 1994. Dueling: The cult of honor in fin-de-siècle Germany: Princeton University Press Princeton, NJ.

Mendez, Théodore Auguste. 1836. Essai sur le duel: Bohaire.

Muchembled, Robert. 2012. A History of Violence: Polity Press, Cambridge.

North, D. C. 1990. Institutions, institutional change and economic performance: Cambridge university press.

North, Douglass, Wallis John J., and Weingast, Barry, 2009, Violence and social orders: A conceptual framework for interpreting recorded human history, New York, Cambridge University Press.

North Douglass, Wallis John J., Webb Steven, and Weingast, Barry (eds.), 2013, In the Shadow of Violence, Politics, Economics, and the Problems of Development, Cambridge, Cambridge University Press.

Nye, Robert A. 1990. "Fencing, the duel and Republican manhood in the Third Republic." Journal of Contemporary History no. 25 (2/3):365-377.

Nye, Robert A. 1993. Masculinity and male codes of honor in modern France: Oxford University Press on Demand.

Powell, Benjamin, and Edward P Stringham. 2009. "Public choice and the economic analysis of anarchy: a survey." Public Choice no. 140 (3-4):503-538.

Reddy, William M. 1997. The invisible code: Honor and sentiment in postrevolutionary France, 1814-1848: Univ of California Press.

Riccetti, L., Russo, A., \& Gallegati, M. 2015. "Financialisation and crisis in an agent based macroeconomic model". Economic Modelling

Rogers, Everett M. 1971. "Social Structure and Social Change" The American Behavioral Scientist 14, (5): 767. 
Schelling, Thomas C. 1978. Micromotives and macrobehavior. 1st ed, Fels lectures on public policy analysis. New York: Norton.

Sharpe, Kevin, 1992, The Personal Rule of Charles I, New Haven \& London, Yale University Press.

Skaperdas, Stergios. 1996. "Contest success functions." Economic Theory no. 7 (2):283-290. doi: 10.1007/bf01213906.

Starkey, David, 2006, Monarchy, London, Harper Press.

Stone, Lawrence. 1965. The crisis of the aristocracy, 1558-1641: Clarendon Press Oxford.

Stringham, E. 2005. Anarchy, state and public choice: Edward Elgar.

Stringham, E. P. 2011. "Anarchy and the law: the political economy of choice" (Vol. 1): Transaction Publishers.

Tarde, Gabriel. 1892. Le duel, Études pénales et sociales. Lyon, Paris: Storck-Masson.

Tesfatsion, Leigh. 2006. "Agent-Based Computational Economics: A Constructive Approach to Economic Theory." In Handbook of Computational Economics, edited by L. Tesfatsion and K. L. Judd, 831-880. Elsevier.

Thimm, Carl Albert. 1896. A Complete Bibliography of Fencing \& Dueling: New York: B. Blom.

Truman, Benjamin Cummings. 1883. The field of honor: being a complete and comprehensive history of dueling in all countries; including the judicial duel of Europe, the private duel of the civilized world, and specific descriptions of all the noted hostile meetings in Europe and America: Fords Howard, \& Hulbert.

Tullock, G. . 1980. "Efficient rent seeking." In Toward a theory of the rent-seeking society, edited by J. M. Buchanan, 269-282. College Station: Texas: A\&M University Press.

Vahabi, Mehrdad. 2011. "Economics of Destructive Power" in Braddon D. and Hartley K., Elgar Handbook on the Economics of Conflict, Cheltenham, Edward Elgar, Chapter 5, pp. 79-104.

Vahabi, Mehrdad. 2016. The Political Economy of Predation: Manhunting and the Economics of Escape, New York, Cambridge University Press.

Volckart, Oliver. 2004. « The economics of feuding in late medieval Germany », Explorations in Economic History, Vol. 41, pp. 282-299.

Wallick, Richard. 2012. "Agent-based modeling, public choice, and the legacy of Gordon

Tullock." Public Choice no. 152 (1-2):223-244.

Weber, Max. 1968. Economy and Society, An Outline of Interpretive Sociology, Volume 1, Edited by Guenther Roth and Claus Wittich, New York, Bedminster Press.

Wells, CA. 2001. "End of the Affair: Anti-Dueling Laws and Social Norms in Antebellum America, The." Vand. L. Rev. no. 54:1805.

Wilensky, U. 1999. NetLogo. Northwestern University. Evanston, IL.: Center for Connected Learning and Computer-Based Modeling. 
Young, Arthur. 1925. A tour in Ireland: with general observations on the present state of that kingdom made in the years 1776, 1777, and 1778, by Arthur Young. Cambridge: C. Maxwell. 